OPEN ACCESS

Edited by:

Leon Grayfer,

George Washington University,

United States

Reviewed by:

Louise A. Rollins-Smith, Vanderbilt University, United States

Carly Rae Muletz-Wolz,

National Zoological Park (SI),

United States

*Correspondence:

Laura F. Grogan

l.grogan@griffith.edu.au

Specialty section: This article was submitted to

Comparative Immunology,

a section of the journal

Frontiers in Immunology

Received: 29 June 2018 Accepted: 15 October 2018 Published: 09 November 2018

Citation:

Grogan LF, Robert J, Berger L, Skerratt LF, Scheele BC, Castley JG,

Newell DA and McCallum HI (2018)

Review of the Amphibian Immune Response to Chytridiomycosis, and

Future Directions.

Front. Immunol. 9:2536.

doi: 10.3389/fimmu.2018.02536

\section{Review of the Amphibian Immune Response to Chytridiomycosis, and Future Directions}

\author{
Laura F. Grogan ${ }^{1 *}$, Jacques Robert ${ }^{2}$, Lee Berger ${ }^{3,4}$, Lee F. Skerratt ${ }^{3,4}$, \\ Benjamin C. Scheele ${ }^{5,6}$, J. Guy Castley ${ }^{1}$, David A. Newell ${ }^{7}$ and Hamish I. McCallum ${ }^{1}$ \\ ${ }^{1}$ Environmental Futures Research Institute and School of Environment and Science, Griffith University, Nathan, QLD, \\ Australia, ${ }^{2}$ University of Rochester Medical Center, Rochester, NY, United States, ${ }^{3}$ One Health Research Group, College of \\ Public Health, Medical and Veterinary Sciences, James Cook University, Townsville, QLD, Australia, ${ }^{4}$ Faculty of Veterinary \\ and Agricultural Sciences, Melbourne Veterinary School, University of Melbourne, Werribee, VIC, Australia, ${ }^{5}$ Fenner School of \\ Environment and Society, The Australian National University, Canberra, ACT, Australia, ${ }^{6}$ Threatened Species Recovery Hub, \\ National Environmental Science Program, Fenner School of Environment and Society, The Australian National University, \\ Canberra, ACT, Australia, ${ }^{7}$ Forest Research Centre, School of Environment, Science and Engineering, Southern Cross \\ University, Lismore, NSW, Australia
}

The fungal skin disease, chytridiomycosis (caused by Batrachochytrium dendrobatidis and $B$. salamandrivorans), has caused amphibian declines and extinctions globally since its emergence. Characterizing the host immune response to chytridiomycosis has been a focus of study with the aim of disease mitigation. However, many aspects of the innate and adaptive arms of this response are still poorly understood, likely due to the wide range of species' responses to infection. In this paper we provide an overview of expected immunological responses (with inference based on amphibian and mammalian immunology), together with a synthesis of current knowledge about these responses for the amphibian-chytridiomycosis system. We structure our review around four key immune stages: (1) the naive immunocompetent state, (2) immune defenses that are always present (constitutive defenses), (3) mechanisms for recognition of a pathogen threat and innate immune defenses, and (4) adaptive immune responses. We also evaluate the current hot topics of immunosuppression and immunopathology in chytridiomycosis, and discuss their respective roles in pathogenesis. Our synthesis reveals that susceptibility to chytridiomycosis is likely to be multifactorial. Susceptible amphibians appear to have ineffective constitutive and innate defenses, and a late-stage response characterized by immunopathology and Bd-induced suppression of lymphocyte responses. Overall, we identify substantial gaps in current knowledge, particularly concerning the entire innate immune response (mechanisms of initial pathogen detection and possible immunoevasion by $\mathrm{Bd}$, degree of activation and efficacy of the innate immune response, the unexpected absence of innate leukocyte infiltration, and the cause and role of late-stage immunopathology in pathogenesis). There are also gaps concerning most of the adaptive immune system (the relative importance of $\mathrm{B}$ and $\mathrm{T}$ cell responses for pathogen clearance, the capacity and extent of immunological memory, and specific mechanisms of pathogen-induced immunosuppression). Improving our capacity for amphibian immunological research will require selection of an appropriate $\mathrm{Bd}$-susceptible model species, the development of 
taxon-specific affinity reagents and cell lines for functional assays, and the application of a suite of conventional and emerging immunological methods. Despite current knowledge gaps, immunological research remains a promising avenue for amphibian conservation management.

Keywords: chytridiomycosis, immune, innate, adaptive, frogs, declines, amphibian, Batrachochytrium dendrobatidis

\section{INTRODUCTION}

Two decades have passed since the discovery and characterization of the devastating amphibian skin disease, chytridiomycosis, caused by two unusual fungal species that likely originated in Asia $(1,2)$. Batrachochytrium dendrobatidis (hereafter Bd) was first detected in the 1990s and is now widespread globally $(3,4)$, whereas B. salamandrivorans (Bsal) primarily affects salamanders (5) and was recently described after arriving in Europe in 2010. Chytridiomycosis is reported to affect $>350$ amphibian species and has had a dramatic worldwide impact on amphibian biodiversity, having caused the decline and possible extinction of greater than 200 species $(6,7)$. Chytridiomycosis has thus been the subject of intense study, with research focused on understanding fungal virulence, pathogenesis, immunology, treatment, and epidemiology [reviewed in (8-11)]. A central aim of this research has been finding ways to mitigate disease in the field to reduce or prevent further species declines and extinctions $(12,13)$.

The evolution of resistance and/or tolerance to infection is a key long-term goal for managing in situ amphibian populations in regions where $\mathrm{Bd}$ is now enzootic (14), and immunological research is central to this goal. A recent study demonstrated that the fungus can maintain high virulence post-emergence (15), which may be a result of its broad host range (where fungal persistence may not be affected by the loss of highly susceptible host species). However, many amphibian species are recovering in the wild (10), and some have increased survival rates consistent with improved immunity (16). A study comparing skin secretion inhibitory activity against Bd pre- and post- emergence suggests that the evolution of natural immunity may be occurring in some species in situ (15). Several studies have made progress uncovering other putative mechanisms for improved immunity, including directional selection of major histocompatibility complex (MHC) alleles (17-21). Unfortunately, many endangered frog species appear to be running out of time. Without sufficient genetic, phenotypic, or behavioral evolution of the host, many susceptible populations remain threatened by chytridiomycosis and are experiencing ongoing declines, sometimes decades post-initial chytridiomycosis outbreaks $(10,22-24)$. Other susceptible species may persist despite chytridiomycosis-associated mortality due to high reproductive capacity. However, compensatory recruitment may be reducing selection pressure for the evolution of immunity (25), and these populations remain highly vulnerable to other threats (26). Furthermore, animals repatriated from captivity continue to succumb to disease in the field $(27,28)$.
While the amphibian immune response to chytridiomycosis has been the subject of some research to date, many aspects remain poorly understood, likely owing to the complexity of the system and the vast range in species' responses to infection. Indeed, Bd and Bsal are the main fungi from their phylum found to cause disease in vertebrates, and the observed host immune response to these pathogens appears to depart from an expected "normal" immune response to an intracellular or fungal pathogen. Previous reviews [e.g., $(11,29-31)$ have covered (1) components of innate immune defenses such as secretion of skin antimicrobial peptides, and maintenance of symbiotic skin bacteria and their antifungal metabolites (29, 32), and (2) adaptive immune components such as MHC allele selection, antibody production, and lymphocyte responses (33, 34). However, the field is overdue for an update that incorporates the results of recent transcriptomic and immunogenetic studies, as well as to provide a more thorough overview of the role of key immune components. Concerning the innate arm of the immune system, virtually nothing is known about the role of pattern recognition receptors (PRRs), complement, cytokines and chemokines, macrophages and dendritic cells, other phagocytes, and natural killer cells. For the adaptive arm of the immune system, besides the possible inhibition of lymphocyte proliferation response by $\mathrm{Bd}$ and importance of antibodies in the skin of infected frogs, very little is known about $\mathrm{B}$ and $\mathrm{T}$ cell responses, immunological memory and antigen detection. Improving our capacity for amphibian immunological research and our understanding of the host immune response to chytridiomycosis may result in numerous applied benefits. These may include: (1) identifying targets for further research, treatment, and marker-assisted evolution, (2) identifying immunologic management strategies including environmental manipulation, vaccine design, selective breeding, genetic engineering and pathogen virulence attenuation, and (3) predicting species at continued risk of decline and implementing timely mitigation measures.

In this review, we present an integrated synthesis of current understanding of the amphibian host immune response to chytridiomycosis within the classical scaffold of innate and adaptive immunological mechanisms [reviewed in (35)]. We have targeted this review for amphibian chytridiomycosis researchers, but we expect it will also be of interest for researchers in the broader fields of fungal immunology and amphibian conservation. We focus specifically on host mechanisms; predominantly in response to $\mathrm{Bd}$ [host responses to Bsal are likely similar but are currently poorly understood; reviewed in (11)]. We do not attempt to review the vast range of factors contributing to variations in susceptibility to infection between 
individuals and species. For a broad introductory overview of chytridiomycosis, see Box 1. For convenience, we provide a glossary of terms and abbreviations in Box 2. Throughout this review, where amphibian-specific immune knowledge is lacking, we instead refer to the better characterized immune system of mammals. Please see Box 3 for a brief comparison between amphibian and mammalian immune systems. We also focus primarily on post-metamorphic and adult amphibians (especially anurans) because larval amphibians (tadpoles) usually survive Bd infections that localize to their keratinized mouthparts (see Box 4 for a brief overview of tadpole vs. post-metamorphic immune systems). We start by outlining several key (non-mutually exclusive) immune stages: (1) the naïve immunocompetent state, (2) immune defenses that are always present (constitutive defenses), (3) mechanisms for pathogen recognition and induction of innate immune defenses, and (4) adaptive immune defenses. For each stage, we briefly describe the expected immune response to an invading infectious organism such as Bd (see Figure 1), then compare it with current knowledge of chytridiomycosis, highlighting research gaps. We then examine and discuss evidence for the role of immunosuppression and immunopathology in chytridiomycosis. We conclude by suggesting future research directions that will contribute to improving mitigation strategies for chytridiomycosis.

\section{THE IMMUNOCOMPETENT UNINFECTED STATE}

Normal uninfected integument of an immunocompetent amphibian host consists of epidermal and deeper dermal layers (Figure 1A). The epidermis constitutes an immediate innate

Box 1 | Amphibian chytridiomycosis-pathogens, infection and disease basics.

\footnotetext{
- The Chytridiomycota are a phylum of microscopic predominantly saprobic fungi with a biphasic life-cycle consisting of motile flagellated zoospores and reproductive zoosporangium (36). Two species within the Chytridiomycota have been well characterized and shown to parasitise vertebrate hosts (Batrachochytrium dendrobatidis $(\mathrm{Bd})$ and $B$. salamandrivorans (Bsal)). These species both infect amphibians causing the disease chytridiomycosis (3-5). The pathogens replicate intracellularly within the deeper cell layers of the host epidermis. In tryptone-gelatin hydrolysate-lactose (TGhL) broth medium at $22^{\circ} \mathrm{C}$, Bd takes $4-5$ days to mature from zoospore to mature zoosporangium (37-39).

- Infections with $\mathrm{Bd}$ and Bsal are restricted to keratinized epidermis of amphibians (mouthparts of anuran tadpoles, skin of adult amphibians). Chytridiomycosis causes a range of changes in the host epidermis including hyperkeratosis, hyperplasia, ulceration, erosions, and necrosis $(5,37)$. In severe infections, clinical signs may include lethargy, abnormal posture, anorexia, peripheral erythema, increased skin shedding (40, 41) and mortality usually over a period of 2-6 weeks post-exposure. Batrachochytrium salamandrivorans infects deep epidermal layers and is more erosive and ulcerative without demonstrating a hyperplastic response. Tadpoles infected with Bd may exhibit blunting of mouthparts and sublethal effects on growth and development (42), but the infection is not usually fatal until metamorphosis and widespread keratinization of the skin (43-45).
}

physical defense barrier against pathogen invasion and consists of cell layers that mature as they migrate toward the skin surface. Epidermal layers include the basal lamina (basement membrane), then the roughly cuboidal or columnar-shaped proliferative cells of the stratum germinativum followed by the stratum spinosum and the stratum granulosum, through to the highly differentiated keratinized squamous epithelial cells found at the surface of the skin, the stratum corneum. These superficial cells are joined by tight junctions, which help maintain the skin barrier $(35,72)$. Intermittent sloughing of the outer layer of the epidermis, the stratum corneum, may assist in the physical removal of skin microorganisms (73). On the surface of this uppermost stratum sits a layer of mucus produced by mucous glands. This mucus contains a number of defensive molecules, including (1) lysozyme and other enzymes produced by phagocytes and keratinocytes, (2) antimicrobial peptides secreted via serous glands, (3) mucosal antibodies, as well as (4) commensal symbiotic bacterial communities together with their secreted antimicrobial compounds [reviewed in $(11,35)]$. A number of peripheral immune surveillance cells are typically present in the epidermis, particularly epidermal dendritic cells including putative Langerhans cells (74), which in Xenopus spp. express high levels of MHC class II molecules $(75,76)$. These various dendritic cells are likely to serve as efficient antigen presenting cells, although this remains to be demonstrated. Dendritic epidermal T cells (DETCs), and gamma/delta $\mathrm{T}$ cells have also been described in Xenopus spp. (76).

The highly collagenous dermis underlies the epidermis. It consists of deeper stratum compactum and thicker and more superficial stratum spongiosum, separated in some species by the substantia amorpha granular calcified layer (77-79). The dermis provides nutrition and sensory integration to the epidermis via a network of capillaries and nerves that course through the dermis. Serous (granular or poison) glands and mucous glands are also present within the dermis, along with pigment-bearing chromatophores and smooth muscle fibers. Serous glands are often widely distributed throughout the skin and are able to discharge their contents in response to noxious stimuli. In the uninfected state, the repertoire of naïve $\mathrm{B}$ and $\mathrm{T}$ lymphocytes lie mainly quiescent within the spleen and blood, as well as in other secondary lymphoid organs such as the liver and intestine (Figure 1A). In amphibians, the spleen functions as the primary and major secondary lymphoid organ. Naïve B and T lymphocytes each possess a unique and specific antigen receptor combination.

\section{EARLY NAIIVE INFECTION AND CONSTITUTIVE DEFENSES}

The earliest stage of the infection process with $\mathrm{Bd}$ involves the likely chemotaxis of infectious zoospores toward the skin surface [Figure 1B, (11, 80, 81)], whereupon they encounter mucus and any associated constitutive defenses of the skin. We discuss these defenses in the context of chytridiomycosis below. 


\section{Box 2 | Abbreviations and glossary of terms.}

- Adaptive immune system: the arm of the immune system mediated by B and T cells, characterized by specificity, immunological memory and recognition of non-self antigens.

- Agglutination: the combination of antibody and antigens forming an aggregate

- Allele: one form of a gene at a single locus

- Antibody (immunoglobulin): glycoprotein molecules capable of reacting specifically and selectively with antigens

- Antigen: a substance that reacts with the products of an immune response (antibodies)

- Antimicrobial peptides (AMPs): small, generally cationic and relatively hydrophobic peptides that have the capacity to damage bacterial and fungal cells

- Anorexia: lack or loss of appetite for food

- Anura: the Order of tailless amphibians that includes frogs and toads

- Antigen presenting cell (APC): a cell that processes and presents antigen in conjunction with major histocompatibility complex molecules

- Apoptosis: programmed cell death

- B cell: a type of lymphocyte capable of synthesizing antibody (immunoglobulin) in response to an antigen, and possessing B cell receptors (BCR)

- Cationic: positively charged ion

- Caudata (or Urodela): the Order of tailed amphibians that includes salamanders and newts

- Chemotaxis: directional movement of a cell in response to a substance gradient

- Codominance: the full expression of both alleles in a gene pair of a heterozygote

- Complement: a set of blood proteins that enhance the ability of antibodies and phagocytic cells to clear pathogens

- Constitutive defenses: forms of defense that are always present, rather than induced by the presence of a stimulus

- Co-stimulation: cell activation requires stimulation by both an antigen and additional molecules

- Damage associated molecular patterns (DAMPs): host molecules that stimulate a non-infectious inflammatory response

- Dendritic cells: cells with a branched structure that act as professional antigen-presenting cells

- Dermis: the skin layer beneath the epidermis that contains blood capillaries, glands and nerve endings

- Ecdysis: the process of shedding/sloughing old skin

- Endocytosis: mechanism whereby substances are taken into a cells via membrane vesicles

- Epibiotic: living on the surface of another organism

- Epidermis: upper layers of skin containing keratinocytes

- Epitope: a small area on an antigen that can combine with an antibody

- Erythema: redness of the skin

- Humoral: immunity based on antibodies

- Hydrophobic: insoluble in water

- Immunocompetent: ability to respond immunologically to a stimulus

- Immunosuppressed: decreased ability to respond immunologically to a stimulus

- Innate immune system: the arm of the immune system characterized by nonspecific responses not requiring previous exposure to similar antigen

- Langerhans cells: phagocytic cells within the epidermis that function as antigen presenting cells

- Ligand: a molecule that forms a complex with another molecule

- Lymphocytes: cells principally of the adaptive immune system consisting of B and T cells

- Lyse: rupture of cell membrane

- Membrane attack complex (MAC): the terminal part of the complement system that comprises 5 proteins that associate together and cause damage to membranes

- Macrophage: a large phagocytic cell found in tissues, derived from monocytes in blood

- Mitogen-activated protein kinase (MAPK): a protein kinase specific to serine/threonine

- MBL-associated serine protease (MASP)

- Mannose-binding lectin (MBL): a C-type lectin that serves as a pattern recognition receptor and when engaged by pathogen molecules, activates the lectin pathway of complement activation

- Major histocompatibility complex (MHC): a chromosomal locus composing multiple genes encoding histocompatibility antigens (cell surface glycoproteins), includes genes encoding both class I and II molecules

- Neutrophil: a type of white blood cell with phagocytic properties and a segmented nucleus

- Nuclear factor kappa-light-chain-enhancer of activated B cells (NFKB)

- Opsonization: coating the surface of antigens or microorganisms with opsonins to facilitate phagocytosis

- Pathogen-associated molecular patterns (PAMPs): molecular motifs broadly expressed by pathogens and not found on host tissues

- Peptidoglycan recognition proteins (PGRPs): a group of pattern recognition receptors capable of recognizing peptidoglycan wall of bacteria

- Phagocytosis: the uptake of particulate materials by a cell for destruction

- Polymorphism: more than one allele occupies a gene's locus within a population

- Pattern recognition receptors (PRR): receptors that recognize molecular patterns of microorganisms

- Rhizoids: filamentous outgrowth

- Saprobic: lives on decaying organisms

- Somatic hypermutation: a programmed process of mutation within the variable regions of immunoglobulin genes

- Somatic recombination: alteration of DNA of a somatic cell

- T cell: a type of lymphocyte that plays a central role in cell-mediated immunity, and possesses T cell receptors (TCR)

- Tumor necrosis factor alpha (TNF- $\alpha$ ) 


\section{Skin Sloughing Increases With Chytridiomycosis and May Physically Reduce Microbial Burdens}

Ecdysis or skin sloughing in ectotherms can function as a constitutive innate immune defense mechanism by physically removing skin microbiota $(73,82)$. Sloughing usually occurs soon after dark, approximately every 3 or 4 days depending on species, and the frequency of sloughing increases with ambient temperature (73). Abnormal sloughing is a clinical sign of chytridiomycosis and corresponds with an increased frequency of sloughing and the production of smaller shed pieces $(3,83,84)$. This may be the result of sporangia initiating premature keratinization and cell death in infected epidermal cells, in concert with hyperplasia and stimulated epidermal turnover as observed by electron microscopy (77). Using infrared video recordings, Ohmer et al. (84) found that while sloughing rate increased with infection, chytridiomycosis did not affect sloughing behavior, duration or rhythmicity, although diseased frogs typically did not eat the sloughed skin as they normally would. Independent of temperature, the extent to which increased sloughing reduces $\mathrm{Bd}$ infection loads varies depending on species' intrinsic susceptibility, and sometimes results in clearance of infection (85). As such, Ohmer et al. (84) hypothesized that skin sloughing may be both beneficial and detrimental in the face of chytridiomycosis (for example, by removing pathogens or symbiotic bacteria, and disrupting skin homeostasis). Of interest, the most resistant species they studied, Limnodynastes tasmaniensis, demonstrated increased sloughing rates at lower infectious burdens, which Ohmer et al. (85) suggested may indicate an effective induced defense response. Increased rates of sloughing in warmer environments, induced as an immune defense, or in association with behavioral fever (86, 87) may partly explain the improved clearance of Bd infection at higher temperatures (88).

\section{Natural Mucosal Antibodies (Generated by Innate-Like B Cells) May Inhibit Zoospores}

Naïve frogs (not previously exposed to $\mathrm{Bd}$ ) are unlikely to express specific mucosal antibodies that bind to and inhibit zoospores (89). However, as occurs in other vertebrates, natural antibodies may be present and may limit initial pathogen burdens. Natural antibodies are polyreactive against highly conserved pathogen epitopes. They are typically encoded by germline genes, and in mammals, they are produced by innate-like B cells (90-92). Little is currently known about their efficacy against Bd in amphibians.

\section{Lysozyme and Other Defensive Enzymes May Limit Zoospore Invasion}

Lysozyme is a constitutively expressed antimicrobial enzyme found in body fluids and mucosal linings. Lysozyme from amphibian skin secretions has potent bactericidal activity (93, 94). Although typically considered an antibacterial enzyme, lysozyme has also been reported to possess antifungal properties $(95,96)$. Thus, amphibian lysozymes may have similar activity against pathogens such as $\mathrm{Bd}(11,31,97)$. To date there is little evidence for the role of lysozyme and other phagocyte-
Box 3 | The immune system of amphibians is similar to other vertebrates.

The larval and adult immune system of amphibians, in particular Xenopus spp. (South African clawed frog), has been subject to extensive investigation as a transitional non-mammalian model organism for comparative and evolutionary immunology and studies of immune ontogeny (46). The adult anuran immune system is fundamentally similar to other jawed vertebrates (47), and responds similarly to antigenic stimulation (48). However, there are some differences.

- Most anurans lack the lymph nodes of mammals (49), and instead rely on the other major lymphoid organs. The spleen represents a primary lymphoid organ (site of lymphopoiesis) and secondary lymphoid organ (site of antigen presentation, $\mathrm{T}$ and B cell antigen-dependent activation and expansion) in amphibians. The thymus and liver are also sites of lymphopoiesis, with lymphocyte aggregations additionally occurring in the liver, kidneys, and intestine (50).

- Many amphibians produce potent antimicrobial peptides in granular (serous) glands of the skin [reviewed in (29)].

- Amphibian innate immune cell types are morphologically similar to those of mammals and include polymorphonuclear cells (neutrophils, eosinophils, and basophils), as well as monocytes, macrophages and natural killer cells (46).

- Many innate immune genes and gene pathway homologs to other vertebrates have been identified in Xenopus spp. (46). These include receptors [polymorphic major histocompatibility class I and II genes, and toll-like receptors; (51)], cytokines (interferon- $\gamma$, interleukins, tumornecrosis factor $\alpha$ ), and complement [classical, alternative, and lectin pathways; (52)].

Although many aspects are still poorly characterized in amphibians (particularly CD4 T helper cell function), adaptive B and T cell biology is fundamentally conserved between mammals and amphibians. However, there are several notable differences.

- Concerning B cell response, the affinity maturation of antibody is relatively poor (10x) in comparison with that in mammals $(10,000 x)$, which may be related to the lack of germinal centers important for the selection of $\mathrm{B}$ cells expressing antigen receptors with higher affinity (50, 53-55).

- The recent characterization of dendritic cells in the spleen that perform the additional duty of follicular dendritic cells (specialized cells critical for antigen-specific B cell activation), further suggests a less powerful B cell response capacity in amphibians $(56,57)$.

- Furthermore, unlike mammalian lymphocytes, many differentiated B cells have phagocytic capabilities (58).

- The antibody responses of adult amphibians also differ slightly from mammals and consist of lgM, lgX (mainly mucosal expression) and lgY (induced via T-cell dependent responses); the latter two are functionally analogous to $\operatorname{lgA}$ and $\operatorname{lgG}$ of mammals (49). Two further isotypes have also been discovered mainly in the spleen, $\lg D$, and $\lg F(59,60)$. $\lg \mathrm{D}$ is homologous to mammal and fish lgD, although lgF does not have a known mammalian homolog (61).

- Similarly to the situation with B cells, while the CD8 T cell response is MHC class I-restricted and critical for host resistance to viral infection (62), CD8 T cell expansion appears to be not as extensive as in mammals (63).

- Finally, a prominent immune surveillance system based on a large family of MHC class I-like genes regulating the development and function of innatelike T cells critical for host antimicrobial defenses has recently been unveiled in Xenopus spp. (64-66). Similar systems are likely to exist across all aquatic vertebrates (67), which will require full consideration in the context of $\mathrm{Bd}$ host responses as well as when analyzing transcriptomics (e.g., issues in distinguishing classical $\mathrm{MHC}$ and $\mathrm{MHC}$-like transcripts).

or keratinocyte-derived constitutive enzymes (e.g., antimicrobial lectins, secretory phospholipase $\mathrm{A}_{2}$ ) in defense against $\mathrm{Bd}$. However, Rosenblum et al. (98) reported an increase in 
Box 4 | Comparison between tadpole and post-metamorphic amphibian immune system.

- The immune system of tadpoles, while competent, is functionally less well developed than the immune system of post-metamorphic and adult amphibians.

- The amphibian immune system undergoes substantial remodeling accompanied by immunosuppression during metamorphosis, through until about 6 months post-metamorphosis $(46,68,69)$.

- The immunoglobulin repertoire is typically smaller and less specific in tadpoles, the thymus involutes and is re-formed during metamorphosis, and the expression of $\mathrm{MHC}$ class I and II molecules greatly expands $(46,47,70)$.

- The combined effects of (1) immune system remodeling, and (2) the development of keratinized epidermis across the body during metamorphosis, may help to explain why newly metamorphosed anurans are particularly vulnerable to chytridiomycosis $(30,43,71)$.

expression of lysozyme genes in the skin of infected Xenopus tropicalis at 21 days post exposure in a transcriptomic study. Grogan et al. (18) similarly identified upregulation of lysozyme C genes in the skin of Litoria verreauxii alpina throughout infection, although the efficacy of this response for limiting Bd infection is currently unknown.

\section{Amphibians Produce a Range of Antimicrobial Peptides With Activity Against Bd, and These Likely Play a Role in Defense}

The antimicrobial peptides (AMPs) of vertebrate skin are typically small hydrophobic cationic peptides produced by serous glands that provide non-specific defense against pathogenic organisms $(99,100)$. Clarke (99) describes four main categories of defensive molecules including alkaloids, steroids, biogenic amines, and other peptides and proteins. The range and quantity of AMPs produced by amphibians is remarkable among vertebrates and has been the target of medical studies for decades, particularly for use in pharmaceutical applications [e.g., (101-103)]. The production of antimicrobial peptides can be induced and modulated by the presence of microbial flora (104) and chronic corticosteroid administration (105). Serous glands release antimicrobial peptides to the skin surface at a low continuous rate, however, mild activation of the sympathetic nervous system (such as alarm caused by a predator cue) is sufficient to stimulate the contraction of gland-associated muscle fibers and the release of larger quantities of AMPs to the skin surface $(89,106)$. It is unlikely that zoospore invasion alone would be sufficient stimulus to produce this response.

Through in vitro growth inhibition assays, many amphibian peptides and peptide mixtures (at concentrations likely to occur in vivo) have been found to inhibit the growth of various pathogens including $\mathrm{Bd}$ as well as other fungi [reviewed in $(31,107)]$. Antimicrobial peptide defenses are considered reliable predictors of natural resistance of amphibians to chytridiomycosis. However, the efficacy of AMPs in defense against Bd appears to vary substantially by species and other factors, which may limit the value of AMP data for predicting and mitigating amphibian declines (108-113). These factors may include: (1) intrinsic peptide efficacy against $\mathrm{Bd}$ as demonstrated in vitro, (2) concentration, number and type of peptides produced, (3) rate and location of release to the skin surface in response to microbial pathogens, and (4) presence of host- and Bd-secreted proteases that may degrade AMPs $(106,114,115)$. For example, depletion of AMPs led to increased infection probability in resistant amphibian species Xenopus laevis (89) and Rana pipiens (116), but not in Pelophylax esculentus and P. lessonae (117). Validation studies involving the functional modification of key AMP molecules are still needed to confirm these associations. Woodhams et al. (118) found that AMP expression differed between infected and uninfected wild-caught Litoria serrata, with infected frogs demonstrating reduced expression. However, they did not identify whether this was a cause or consequence of infection. Ribas et al. (119), Rosenblum et al. (120) identified AMP genes or precursors (including preprocareulein and cathelicidin) via microarray studies of the spleen and skin of frogs. More recently, comparing the anti-Bd activity of skin secretions collected from frogs before and after Bd emergence in Panama, Voyles et al. (15) found a significant increase in inhibitory efficacy post-emergence, consistent with an evolutionary shift in the host immune response. The mechanisms underlying this change in efficacy are unknown but may involve altered concentration and diversity of peptides or improved inhibitory function.

\section{The Skin Microbiome May Inhibit Zoospore Colonization, and Bioaugmentation May be an Effective Management Strategy}

Commensal microbial communities are present in the mucus layer on amphibian skin and may provide another mechanism of constitutive innate immunity against $\mathrm{Bd}$ via several mechanisms (32, 61, 121). For example, Meyer et al. (82) reported the cultivation of approximately $0.5-1.7 \times 10^{6}$ bacterial colonies and 1.6-2.6 $\times 10^{4}$ fungal colonies per square $\mathrm{cm}$ of dorsal skin of Rhinella marina. Interestingly, detected microbial loads were much lower on ventral skin, despite being in more frequent contact with moist substrates than the dorsum. Many bacteria and fungi secrete antimicrobial compounds with repellant and growth-inhibitive properties against pathogenic microbes (122124). Furthermore, microbiota may also compete directly with $\mathrm{Bd}$, and may functionally change host immune responses (121).

Numerous epibiotic bacterial species isolated from amphibian skin are growth inhibitive for Bd in vitro $(125,126)$. For example, the bacterial species Janthinobacterium lividum has shown particular promise for the anti-Bd properties of its secreted metabolite violacein, at concentrations greater than $15 \mu \mathrm{M}$ (127). In clinical Bd exposure experiments, both frogs (Rana muscosa) and salamanders (Plethodon cinereus) inoculated with J. lividum did not become infected (128), whereas depletion of bacteria resulted in high Bd infection intensities (129). This effect also extended to soil augmentation and environmental 


\section{A Normal skin}
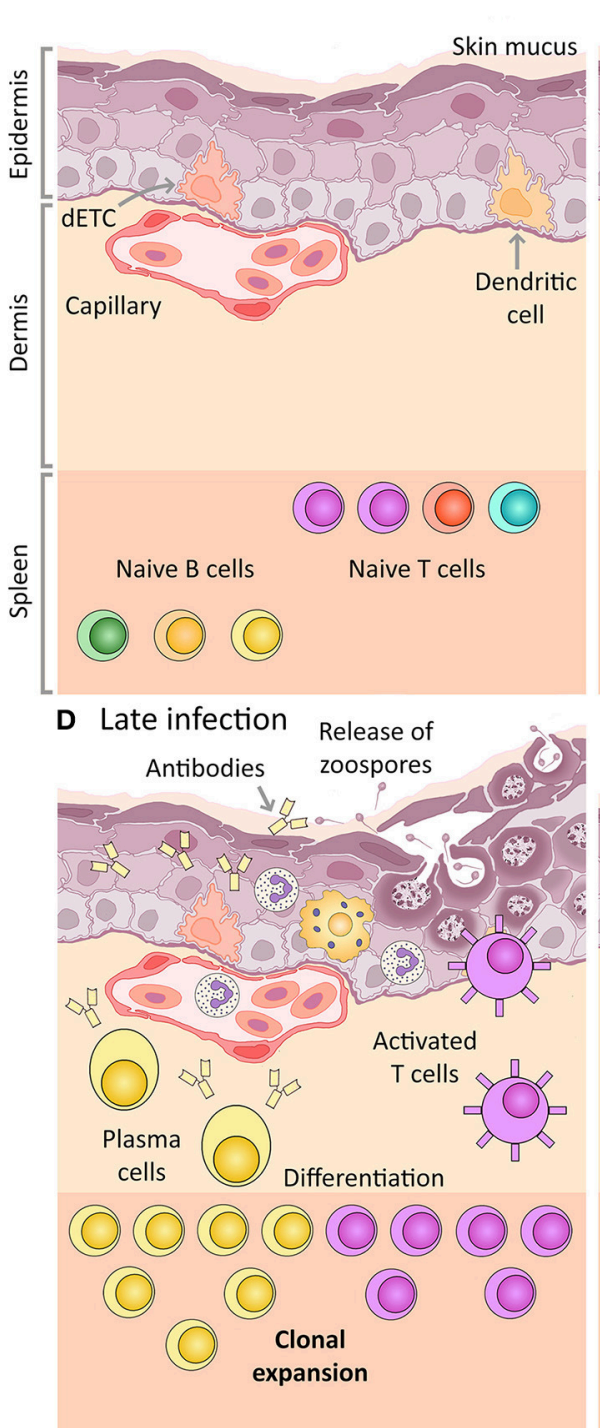

\section{B Early infection}

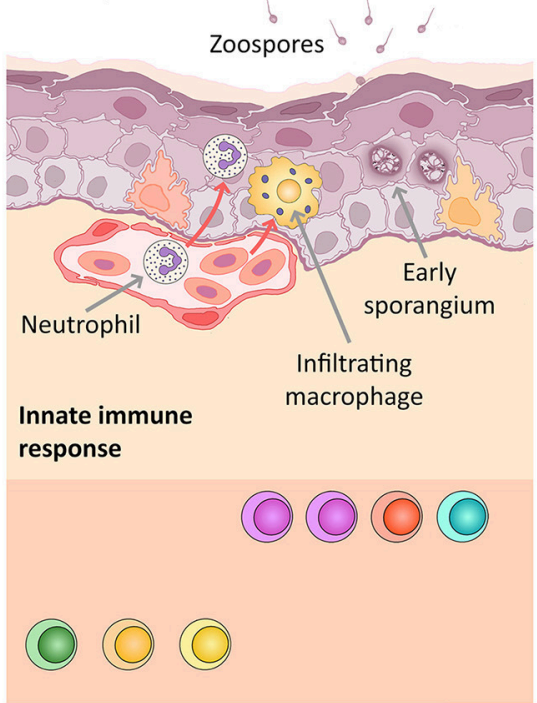

E Recovery

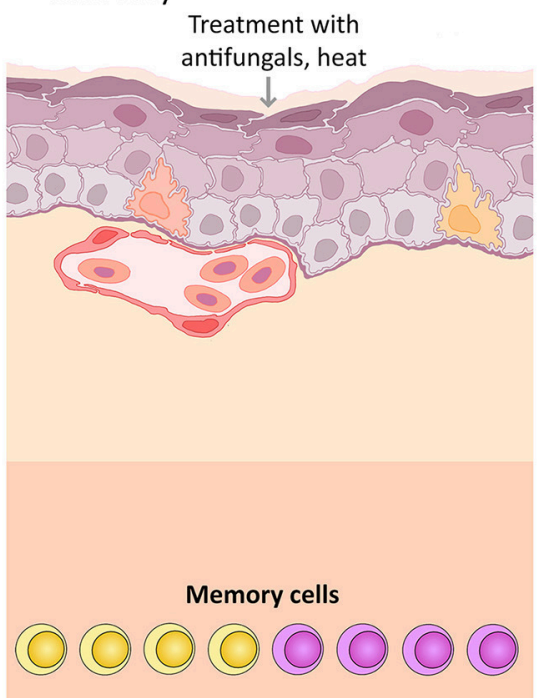

\section{Intermediate infection}

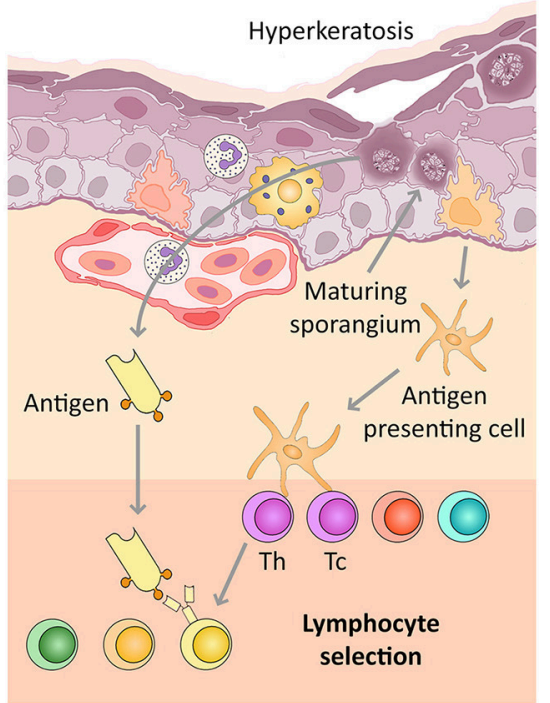

\section{F Re-exposure}

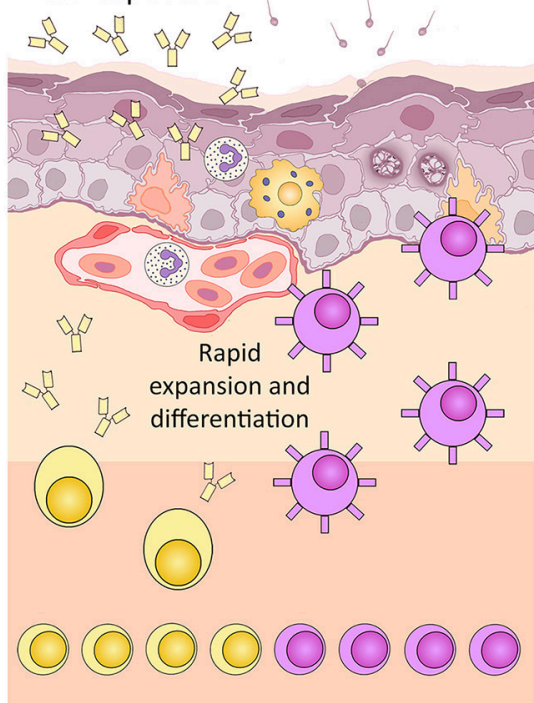

FIGURE 1 | Amphibian host immunity schematic, depicting a histological section through the skin and progressive infection stages with Bd. The inference of the main cellular components is based on mammalian immunology and an expected "normal" immune response (including the expected response to vaccination). (A) Normal skin: Layers of uninfected frog skin epidermis including, from deepest to most superficial, the basal lamina, stratum germinativum, stratum spinosum, stratum granulosum, stratum corneum and the superficial mucus layer. Two immune surveillance cells are illustrated within the epidermis, an immune dendritic cell (homologous to Langerhans cell), and a dendritic epidermal T cell (dETC). Within the dermis is a capillary with the nucleated red blood cells of amphibians. An example complement of naive B and T lymphocytes are depicted waiting quiescent in the spleen, illustrated schematically as the lower band on the figure (please note that the spleen is a separate organ and does not lie adjacent to the dermis in living amphibians). (B) Early infection: Expected immune mechanisms upon initial exposure to $\mathrm{Bd}$, assuming constitutive defenses (such as AMPs and bacteria) are insufficient. Zoospores are illustrated penetrating the mucus layer, and early thalli with zoosporangia developing are illustrated inside deeper host cells. In a normal immune response, pathogen recognition should lead to the infiltration of innate immune cells, illustrated here to include macrophages and granulocytes (such as neutrophils). (C) Intermediate infection: Expected response at an intermediate stage of infection includes the recognition of antigens by dendritic cells that then differentiate into antigen presenting cells and migrate to the spleen enabling antigen-specific selection of lymphocytes. Simultaneously, membrane-bound immunoglobulin on naïve B lymphocytes is exposed to extracellular Bd antigens (transported via the blood circulatory and lymphatic systems). With the assistance of T helper cells, these B cells are activated to respond to infection. (D) Late infection: The late adaptive response involves lymphocyte clonal expansion, differentiation into plasma cells and activated T cells (including cytotoxic and helper T cells), as well as the production of antibodies by plasma cells. (E) Recovery: If the frog is cleared of infection (perhaps by topical antifungals or heat), the skin might be expected to return to normal, however, a cohort of selected memory lymphocytes should remain. (F) Re-exposure: If the frog is then later re-exposed to Bd, the memory lymphocytes (produced during the previous clonal expansion) are then activated and induced to replicate and differentiate, leading to a much more rapid and effective adaptive immune response on re-exposure. This is the concept of immunization (vaccination). 
transfer of bacterial species to some amphibian hosts, thereby inhibiting Bd infection, at least temporarily $(130,131)$. Despite these promising results, outcomes in other species are mixed. For example, inoculation of Panamanian Golden frogs (Atelopus zeteki; extinct in the wild) with probiotic bacteria was not associated with improved survival $(132,133)$.

There is some evidence for population-level correlation between the presence of (and proportion of individuals harboring) anti-Bd bacterial species and population declines $(134,135)$, although not all studies corroborate these findings (136). The presence of diverse bacterial communities in addition to anti-Bd bacterial species on amphibians, and synergy (or antagonism) between bacteria and AMPs, will affect the degree of Bd growth inhibition as demonstrated in vitro (137-139). Other field studies have shown that skin microbial communities differ consistently between Bd-susceptible and resistant/tolerant species, as well as between sites with differing infection histories $(121,140)$. It is unclear from these studies whether identified bacterial communities promote $\mathrm{Bd}$ tolerance or resistance, or are the result of it (121). Further applied work should target probiotic candidate selection and trial bioaugmentation approaches (32, 141, 142).

\section{INNATE IMMUNE DEFENSES}

If the invading Bd zoospores are not contained with constitutive host defenses, then they encyst upon the keratinized skin surface and attach via adhesive molecules $(11,77)$. Germination tubes are then sent through one or more cell layers $(143,144)$, injecting the contents of the zoospore cyst into the cytoplasm of deeper cells of the host epidermis, including the stratum spinosum and stratum granulosum [Figure 1B, (3)]. The intracellular location and process of injecting zoospore contents into deeper epidermal cells may permit $\mathrm{Bd}$ evasion of host immune surveillance, as has been described with other fungal pathogens (98, 145-147).

\section{Pattern Recognition Receptors Detect Common Fungal Structures and Initiate Inflammation, Although There Is Currently Limited Data to Assess Their Role in Chytridiomycosis}

In the absence of targeted immune evasion, an invading microbe should prompt host recognition. Mechanisms responsible for pathogen recognition induce innate then adaptive immune responses in the host via antigens either secreted, expressed on the pathogen cell surface, or processed after phagocytosis. These antigens often contain widely recognized structural moieties known as pathogen-associated molecular patterns (PAMPs) that are common among different groups of microorganisms. These PAMPs bind to host germline-encoded pattern recognition receptors (PRRs) expressed within or on cells of the innate immune system (macrophages, dendritic Langerhans cells) and nonprofessional immune cells (keratinocytes, fibroblasts) [reviewed in (35)]. In mammals, four classes of PRRs include: (1) Toll-like receptors (TLRs) and (2) C-type lectin receptors
(CLRs) within cell membranes, (3) NOD-like receptors (NLRs), and (4) Retinoic acid-inducible gene (RIG)-I-like receptors (RLRs) within the cytoplasm of host cells (148). Binding of PAMPs by PRRs leads to an innate amplifying inflammatory cascade that varies depending on the initial signaling pathways involved. Binding of PRRs may induce signaling pathways and the release of cytokines [pathways such as nuclear factor kappa-light-chain-enhancer of activated B cells $[\mathrm{NF \kappa B}]$, and mitogen-activated protein [MAP] kinase]. Binding may also stimulate phagocytosis and destruction of extracellular microorganisms, or cell-mediated cytotoxicity and apoptosis of infected host cells [reviewed in (35)]. Patin et al. (149) presents an extensive review of existing knowledge about fungal recognition in mammals via PRRs, and lists common fungal ligands including $\beta$-glucans, zymosan, mannose, phospholipomannan, unmethylated DNA, and chitin.

Little is known about PRRs and their interactions with fungal pathogens in amphibians, although genes homologous to mammalian PRRs are present in model amphibian genomes (e.g., Xenopus spp.). The expression pattern and inducibility of TLRs has been studied to some extent in Xenopus spp. and Rana catesbeiana $(51,150)$. To date there is little evidence for early upregulation of PRR-coding genes in frogs infected with any pathogens (including $\mathrm{Bd}$ ), although this may be the result of a lack of early immune cell infiltration rather than a lack of constitutive recognition by nonprofessional immune cells per se. However, studies with detailed kinetic analysis appropriate for examining early innate immune responses in amphibians are currently lacking. For example, Grogan et al. (18) did not find any evidence of differentially expressed Dectin genes (key members of the CLR family for detecting common fungal pathogens) at any point during infection, compared with uninfected control frogs. However, several other putative PRRs (TLRs and NLRs) and their downstream signaling pathways were found upregulated in the skin of frogs during late stage infections $(18,98,151-153)$. Representatives of these pathways included mannose-associated genes, fc receptor 5 genes, NFKB subunit genes, caspase 6, 7, and 10 analog genes, and MyD88 pathway genes (18). These results from across the several species studied suggest that putative PRR-encoding genes are present and are likely activated. Although, it is possible that the pathogen actively interferes with these pathways, such as the inhibition of NFKB detected by Rosenblum et al. (120). We currently lack sufficient evidence to determine the efficacy of the early innate immune response to $\mathrm{Bd}$. The detected late gene activation of these downstream signaling pathways may alternatively be associated with cellular stress and trauma or secondary bacterial infections (151), producing damage associated molecular patterns (DAMPs) that are similarly recognized by PRRs and protease-activated receptors (PARs) (154). These findings are consistent with the results of Brem and Parris (155) who showed that toads were less likely to be become infected if the epidermis was scraped (causing erosions) prior to Bd exposure. Priming of the innate immune system in response to trauma (Bd-associated epidermal erosions) may contribute to amplification of the innate response, leading to an exacerbated late-stage response. Similar 
immune priming may have applications for infection mitigation strategies. The precise characteristics of pathogen recognition and signaling may be further elucidated by detailed kinetic studies.

\section{The Alternative Complement Cascade May be Important for Early Defense in Resistant Individuals}

The complement system constitutes a set of receptors and soluble plasma proteins and enzymes with an important role in defense against pathogens. Complement activation stimulates a rapid cascade of molecular interactions triggered by bound antibodies and PAMPs that results in formation of the membrane attack complex (MAC) and plays a central role in innate defense against fungal infections [reviewed in (156)]. Bound complement components function to agglutinate extracellular pathogens and lyse their cell membranes, as well as attract phagocytes to the locality and enhance their phagocytosis of pathogens via opsonization. Although considered most capable at neutralizing extracellular pathogens, complement C3 binding prior to pathogen intracellularization can activate autonomous immunity within infected cells (via NFKB signaling), ultimately leading to cell destruction via apoptosis (157). The complement cascade may be activated via three mechanisms. The first mechanism is the classical pathway (triggered by antigenantibody complexes, bacterial lipopolysaccharide, pentraxins such as C-reactive protein [CRP] and serum amyloid, etc.). A second mechanism is the alternative pathway (recognizes pathogen associated patterns or PAMPs). The third mechanism of activation is via the lectin pathway (recognizes carbohydrate structures via mannan-binding lectin [MBL], MBL-associated serine proteases [MASPs], and ficolins) [reviewed in (156)]. It is noteworthy that all elements of the complement system are well conserved across jawed vertebrates (158), such that with Xenopus spp. antiserum, it is possible to use purified mammalian complement to lyse amphibian red blood cells (159).

As an early and rapid defense response, examining the extent of complement activation may be critical for assessing the efficacy of the innate immune response. Several studies thus far have indicated early downregulation of complement pathway genes $(98,119,120)$ in the infected skin of several susceptible species. In contrast, Grogan et al. (18) found that gene analogs associated with the alternative complement pathway (venom factor 1 and complement factor B) were upregulated from the early infection stage in a phenotypically more resistant population of Litoria verreauxii alpina frogs, but only upregulated at later infection stages in more susceptible populations (18). This is consistent with studies in a variety of species where complement pathway genes were predominantly upregulated in late-stage infection (151-153). These findings may indicate that the alternative complement pathway plays an important role in defense against $\mathrm{Bd}$ in more resistant individuals. However, Bd may downregulate or fail to activate the complement cascade in susceptible individuals, at least until the late infection stage (98). Further research on activation of the alternative complement pathway may provide genetic markers for resistance and opportunities for selective breeding or genetic engineering.

\section{There Is Limited Data to Assess Cytokine Upregulation in the Crucial Early-Stage Infection Period}

Cytokines are endogenous inflammatory mediators and include lymphokines (such as macrophage activating factor [MAF]), interleukins (ILs), tumor necrosis factors (TNFs), interferons (IFNs), transforming growth factors (TGFs), chemokines, colony stimulating factors (CSFs), polypeptide growth factors (GFs), and stress proteins [including heat shock proteins (HSPs)]. Proinflammatory cytokines can act on adjacent cells or distant cells via the systemic circulation to amplify the inflammatory cascade, attract leukocytes to the site of infection, activate pathways involved in blood coagulation, and promote tissue repair [reviewed in (35)].

Experimental studies performed on chytridiomycosis thus far have lacked sufficiently early time-points (i.e., 6-24h postexposure) and infection-targeted tissue sampling strategies to evaluate expression of putative cytokines or their encoding genes. However, gene expression studies sampling tissues between 3 and 8 days post exposure have reported limited evidence for upregulation of putative cytokine-encoding genes. These included IL-17A/F-like gene, calcineurin IL-2 inducible gene, HSPs, TNF associated factor (TRAF) and guanylate binding protein IFN inducible gene in spleens of $X$. tropicalis (98, 119), IFN and IL-associated genes in Rana spp. (120), and IL1B, IL-17C, and IL-17E, TNF $\alpha$, IFN and IFN-induced genes, granulocyte colony-stimulating factor, and several chemokineassociated genes in Litoria verreauxii alpina (18). In contrast, studies of late-stage infections demonstrated changes across the spectrum of cytokines (numerous IFNs, ILs, TNFs, and chemokines), with the most dramatic responses observed in skin tissues from the most susceptible individuals $(18,151,152)$. Of particular interest, several gene expression studies on multiple species identified significant upregulation of numerous IFNinduced very large GTPase gene analogs throughout infection $(18,151,160)$. Interferon-induced GTPase signaling is important for eliminating intracellular pathogens in epithelial cells via their sequestration and destruction within inflammasomes [thought to be especially important for defense against skin fungal pathogens (161)], and thus could be a key mechanism of cellautonomous immunity in chytridiomycosis (162). From these results, it appears that putative cytokine pathways are active in host response to $\mathrm{Bd}$, although we currently have insufficient data to evaluate their relevance in the immediate post-exposure period. The reported upregulated late-stage cytokine responses may instead represent immunopathology from a dysregulated and non-protective immune response $(18,151)$.

\section{There Is Limited Evidence for Innate Leukocyte Recruitment and Infiltration Throughout Infection}

Recruitment of leukocytes (immune effector cells) to the site of infection is a central component of the host immune response. 
Leukocytes of the innate immune system include circulating monocytes that differentiate into macrophages at the site of infection, polymorphonuclear phagocytes including neutrophils, eosinophils, and basophils, as well as natural killer cells and mast cells. These leukocytes contribute to recruit lymphocytes at the site of infection, amplify the inflammatory cascade, destroy extracellular pathogens via phagocytosis, and trigger apoptosis of damaged or infected host cells [reviewed in (35)].

The cellular immune response in chytridiomycosis appears inconsistent and is generally mild or decreased across species $(48,163)$. These studies largely compared skin and blood of Bd-infected and uninfected control frogs. For example, Woodhams et al. (111) found decreased circulating neutrophils and eosinophils, and increased numbers of basophils in infected adult Litoria chloris frogs. Davis et al. (164) and Peterson et al. (165) found increased circulating neutrophils and fewer eosinophils in infected Rana catesbeiana tadpoles and Litoria caerulea adults respectively [Peterson et al. (165) also found low circulating lymphocyte numbers [lymphopaenia]]. These results are consistent with a classic mammalian acute stress response [with the exception of the absence of lymphopaenia in the former study, (166)]. Young et al. (48) found lower circulating total white blood cell numbers in chronically infected adult $L$. caerulea, with overall impairment of responses on immune stimulation, and relatively higher neutrophil to lymphocyte ratios in infected frogs. These variable results may indicate that other unaccounted factors are playing a role (such as corticosteroid levels), or that species' responses differ.

The cellular immune response within skin tissue appears inconsistent from studies thus far performed. For example, histopathology has revealed a variable mild inflammatory response in $10-40 \%$ of skin sites, involving foci with macrophages and few neutrophils. This mild response is also often present near areas of ulceration suggesting a possible association with secondary bacterial infections $(77,151,167,168)$. No evidence of specific leukocyte-associated gene upregulation has been reported during early infections in gene expression studies performed thus far. However, during late-stage infection, Rosenblum et al. (98) found a mild increase in neutrophil-associated genes in the skin and liver of infected Xenopus tropicalis frogs, while Ellison et al. (151) and Grogan et al. (18) found predominantly increased expression of several macrophage and neutrophil associated genes. Taken together, these results indicate that an early leukocyte response is weak or lacking with $\mathrm{Bd}$ infection, and furthermore, that the late-stage response is inconsistent and likely insufficient to limit $\mathrm{Bd}$ infection (and may alternatively be associated with epidermal damage or secondary bacterial infection). This overall observed poor inflammatory response with $\mathrm{Bd}$ infection could be the result of inadequacy of innate immune activation with minimal cytokine-mediated leukocyte recruitment toward Bd. This could possibly be associated with immunoevasion and/or active suppression of immune responses by Bd. However, a limited innate immune response, particularly in late stage infections, may also be symptomatic of an inadequate or impaired adaptive immune response to $\mathrm{Bd}$ (discussed below).

\section{ADAPTIVE IMMUNE RESPONSE}

The adaptive immune system provides a more specific defense against invading pathogens compared with the innate immune system, although it is slower to manifest initially. Amphibian pathogen-specific antibodies (IgY) are undetectable after initial ranaviral infection as is the case in mammalian response to primary infection with large DNA viruses (169). However, in mammals, antibody responses typically improve in efficacy upon subsequent exposures to the same pathogen [Figures 1C-F; reviewed in (35)], and studies performed in amphibians with Frog Virus 3 and Bd support this finding. Between two and three exposures to a pathogen over 4-6 weeks resulted in a detectable pathogen-specific IgY antibody response $(89,169,170)$. These antibodies were detectable at 1 week after the last exposure, and peaked between 2 and 3 weeks. This means that the adaptive immune response may be most critical for infections that fail elimination by non-specific mechanisms of the innate immune response. In comparison with mammalian immune responses, the amphibian adaptive immune response is typically slower to manifest, and of lesser magnitude and efficacy. The adaptive immune system is also dependent on initial activation and costimulation by receptors and mediators of the innate immune system [reviewed in (35)]. However, as we have detailed in the previous sections, the innate immune response to Bd-infection appears somewhat inadequate, at least in the critical early stages of infection (first few days post exposure), and this may reduce the efficacy of the adaptive immune response.

\section{Key Components of the Adaptive Immune Response, Pathogen Specificity, and Immunological Memory}

The primary components of the adaptive immune system include lymphocytes ( $\mathrm{T}$ and $\mathrm{B}$ cells) and their respective mature effector forms responsible for enacting pathogen-specific cell-mediated immunity (cytotoxic or helper T cells) and humoral immunity (antibody-secreting plasma cells) together with secreted or membrane-bound antibodies (immunoglobulin). Unlike the germline-encoded components of the innate immune system, the adaptive immune system is characterized by unique antigen receptors. $\mathrm{T}$ and $\mathrm{B}$ cell receptors are generated when segments of immunoglobulin genes are rearranged by a unique process called somatic recombination. This can occur via $\mathrm{V}, \mathrm{D}$, and $\mathrm{J}$ (variable, diversity, joining) mechanisms, which require products from recombination-activating genes (RAGs). This gives rise to millions of naïve $\mathrm{T}$ and $\mathrm{B}$ cells during the development of an individual, with numerous distinct cell clones bearing unique surface receptors that together constitute the unique lymphocyte receptor repertoire of the host. Lymphocytes activated by antigen binding in combination with co-stimulatory molecules (Figure 1C) undergo clonal expansion and differentiation into their effector forms (Figure 1D). B cell receptors additionally undergo further changes after activation. This involves somatic hypermutation mediated by activationinduced cytidine deaminase (AICDA), which is accompanied by class switching during affinity maturation. During this clonal 
expansion process, large numbers of antigen-specific long-lived memory lymphocytes are produced (Figure 1E), and upon reexposure to the pathogen or antigen, these memory lymphocytes respond more rapidly and effectively than the initial response (Figure 1F). Thus, not only is the adaptive immune system able to respond in a specific way to novel pathogens, but it adapts to those pathogens during the course of an infection. Assuming that the individual survives initial infection, a functioning adaptive immune response should increase in efficacy with subsequent exposures to a pathogen (or antigen) during an individual's lifetime (unlike the innate immune response), leading to the concept of immunization [or vaccination; reviewed in (35)].

\section{The Role of PRRs, MHC and Dendritic Cells for Activation of the Adaptive Immune Response}

Initial activation of the adaptive immune system involves the detection of pathogen-derived antigens by binding to PRRs expressed by host cells. Antigen binding stimulates endocytosis, degradation of the pathogen, and subsequent presentation of the antigen peptide on the cell surface via major histocompatibility complex (MHC) proteins. The two classes of MHC molecules, classes I and II, are expressed differently by cells of the body, and interact with different subsets of lymphocytes. MHC class I molecules are expressed by most nucleated somatic cells (for example, non-immune epithelial cells) and interact with CD8 cytotoxic $\mathrm{T}$ cells, leading to cytotoxicity and death of the host cell expressing antigen with the MHC class I molecule. MHC class I molecules are particularly important for recognition and elimination of intracellular pathogens via cell killing. MHC class II molecules are mainly expressed by professional immune cells such as dendritic cells and macrophages. These cells also recognize pathogens, but can present the antigen via the $\mathrm{MHC}$ class II molecules at the cell surface [reviewed in (35)]. Antigen binding then promotes differentiation of dendritic cells into antigen presenting cells (APC), and TNF- $\alpha$ stimulates APC migration to the spleen via the lymphatic or circulatory system where they contact lymphocytes with a variety of antigen-specific receptors (Figure 1C). MHC class II molecules bound to antigen on the surface of APCs interact with CD4 T helper cells in the presence of other co-stimulatory molecules, and their main function is to activate other immune effector cells (such as B cells; Figure 1C). Co-stimulatory molecules are expressed on APCs in response to mediators of the innate immune system (such as TLRs and $\mathrm{NF \kappa} B$ ), and they are essential for the activation of the naïve CD4 T helper cells.

\section{MHC Genes Associate With Survival and Are Under Positive Selection, Supporting the Rapid Evolution of Resistance or Tolerance to Bd}

The diversity of MHC proteins expressed by cells is generated by polygeny (the presence of multiple interacting genes), allele codominance, and gene polymorphism [reviewed in (35)]. The evolution of MHC genes has been widely demonstrated to occur under selection by infectious diseases (171). Their inter-generational heritability (unlike $\mathrm{T}$ and $\mathrm{B}$ cell receptors) makes them important bridging elements between the innate and adaptive immune systems, and potential markers for selection of either resistance or tolerance to infection (14, 34, 172). Genes encoding MHC classes I and II molecules have been found to be upregulated throughout Bd infection, particularly within skin tissues $(18,34,120,151,153)$. A variety of studies have demonstrated associations between characteristics of MHC alleles (allelic diversity, degree of heterozygosity, presence of certain alleles, presence of certain protein conformational elements) and degree of Bd susceptibility as it differs between species, populations and individuals (17, 20, 21, 173). Furthermore, several studies have demonstrated signals of positive selection at certain MHC loci in populations persisting with enzootic $\mathrm{Bd}$, when compared with background levels of neutral genetic change $(17,20,21)$. These findings suggest that certain MHC genes and alleles may play an important role in determining degree of Bd susceptibility, and that these are under directional selection for resistance or tolerance to $\mathrm{Bd}$. However, recent recognition of the expansion of MHC class I-like genes in Xenopus spp. and presumably other ectothermic vertebrates [see Box 3; 64, 65] may require a revisit of some of the reported studies, especially transcriptomics. Indeed, MHC class I-like genes encode molecules with typical MHC primary structures but are polygenic and not or minimally polymorphic (66).

\section{Both Cell-Mediated and Humoral Immunity Are Likely Important for Defense Against}

Bd

When lymphocytes are activated in the presence of peptidic antigen bound to MHC with appropriate co-stimulation, they proliferate by clonal expansion, differentiate into their effector type and migrate to the site of infection (Figure 1D). CD8 T lymphocytes stimulated by MHC class I-bound antigens differentiate into cytotoxic $\mathrm{T}$ cells that recognize and kill infected host cells. This form of cell-mediated immunity is likely to be especially important for intracellular pathogens such as $\mathrm{Bd}$, as the most efficient means to eliminate the reproductive stage of the pathogen (zoosporangium) is to destroy infected host cells (31). However, B cells and their differentiated effector type (plasma cells) are likely to be similarly important for eliminating Bd. Unlike in mammals, amphibian B cells demonstrate phagocytic capabilities (58). B cells may also act as antigen-presenting cells for $\mathrm{T}$ helper cells, and their effector plasma cells produce antibodies (immunoglobulin, either membrane-bound or secreted) that may be capable of targeting and destroying extracellular pathogen stages such as zoospores and secreted toxins, as well as killing infected host cells. Antibodies target pathogens and kill infected host cells via a suite of mechanisms including (1) binding specifically with the epitope of the antigen and causing the antigens to agglutinate, inactivating them, (2) activating the classical complement cascade, leading to the membrane attack complex to lyse pathogens directly, and (3) antibody-dependent cellmediated cytotoxicity (ADCC) involving tagging antigens for destruction by natural killer cells or phagocytes [reviewed in 
(35)]. Thus, both cell-mediated adaptive immunity ( $\mathrm{T}$ cell elimination of the intracellular reproductive stage of $\mathrm{Bd}$ and $\mathrm{B}$ cell phagocytosis) and antibody-dependent humoral immunity [destroying zoospores and secreted products) are likely to be important for controlling Bd burdens (31)].

\section{There Is Limited Evidence for an Effective Adaptive Immune Response to Bd Infection}

Although it has been suggested that herd immunity may protect populations if $>80 \%$ of frogs are immune (or resistant, through the effects of symbiotic bacteria) to $\mathrm{Bd}(134,135,174)$, there is currently little evidence to suggest that herd immunity operates in wild amphibian populations. Indeed, the existence of a herd immunity threshold relies on infection transmission being density-dependent, rather than frequency-dependent, as is expected for amphibian breeding aggregations (175). Similarly, herd immunity thresholds are unlikely to occur where the force of infection is unaffected by the presence of resistant individuals, as is the case for indirectly transmitted pathogens and those with multiple host species (or life-stages) with differing tolerance and susceptibility to Bd infection. Instead, the temporal patterns of enzootic Bd infection appear regulated by season and temperature rather than adaptive immunity in field populations (22). The few laboratory studies performed to date support these findings, suggesting limited activation of a protective adaptive immune response to chytridiomycosis. Young et al. (48) reported a decrease in total and IgY serum antibody responses [via anti-sheep red blood cells [SRBC] haemagglutination assay] in Bd-infected L. caerulea compared with uninfected frogs, while circulating numbers of lymphocytes were greatly reduced in infected frogs $(48,165)$. Results from histopathology of the skin showed only a mild response with foci of lymphocytes associated with regions of ulceration, or no evidence of lymphocytes (77, $163,167,168)$. In terms of gene expression results, Rosenblum et al. (98) found no change in lymphocyte markers or MHC genes in $X$. tropicalis. Results were similar in their second study on Rana spp. (120) despite mild upregulation of MHC class II genes in the skin during late-stage infection. Ribas et al. (119) found that adaptive immune genes were generally downregulated in the spleen of $X$. tropicalis throughout infection. In contrast, other studies demonstrated upregulation of numerous adaptive immune genes associated with $\mathrm{B}$ and $\mathrm{T}$ lymphocytes, immunoglobulins and MHC genes, particularly in skin tissues at late stages of infection $(18,151,160,176)$. However, a countering signal of downregulated $\mathrm{T}$ cell associated genes was also detected in several studies $(18,151,152)$. These conflicting results indicate a more complex set of interactions operating within the adaptive immune system, which may be associated with the different temperatures at which animals were exposed or housed as well as the timing of collection of samples. The latter finding of downregulated $\mathrm{T}$ cell responses is particularly important and will be discussed in detail in its own section below.

Immunization against $\mathrm{Bd}$ was suggested early on as a management strategy for chytridiomycosis (177) given the highly successful examples from humans and domestic animals (178). Studies reported by Rollins-Smith et al. (31) and Ramsey et al. (89) attempted to immunize Xenopus laevis frogs against chytridiomycosis via an intraperitoneal injection with heat-killed Bd. They found promising results with a high-titer pathogenspecific IgM and IgY serum antibody response in the immunized frogs at 14 days post final immunization. In another experiment, Bd-binding mucosal antibodies (IgM, IgY, and IgX) were demonstrated after repeated exposure to Bd (89). These results are supported by the finding of upregulated immunoglobulin genes in re-exposed Atelopus zeteki frogs, suggesting production of memory lymphocytes (151). Furthermore, X-irradiation of frogs to impair T cells increased Bd infection loads in $X$. laevis (89). In contrast, a repeat experiment with killed-Bd injections into the dorsal lymph sac (days 0 and 14) and peritoneum (day 28) of $X$. laevis followed by splenocyte culture with $\mathrm{Bd}$ showed generally weak lymphocyte proliferation in comparison with samples cultured with phytohaemagglutinin (PHA) alone (31). In another experiment, young boreal toads (Bufo boreas) were immunized following a similar protocol and then exposed to $\mathrm{Bd}$, however there was no evidence for a difference in survival between the immunized and sham-injected exposed frogs, suggesting that the immunization had not been successful in stimulating protective adaptive immunity in the young toads (31). Stice and Briggs (179) immunized Rana muscosa with formalin-killed $\mathrm{Bd}$ in combination with adjuvants [saline, Freunds Complete [FCA], and Incomplete Adjuvant [FIA]] by injection into the dorsal lymph sac and found no differences in the proportion of frogs infected nor time to infection. A study by Cashins et al. (180) did not detect any evidence for a protective effect of prior infection on re-exposure in Litoria booroolongensis. However, a study in B. boreas by Murphy et al. (181) found that previously exposed frogs survived slightly longer if they had a dry habitat option upon re-exposure. A study by McMahon et al. (182) found that multiple prior exposures to Bd slowed the rate of progression of chytridiomycosis, although this finding may instead be associated with repeated innate immune priming through trauma (155). The variable results of these studies may be associated with differing routes of immunization or dose-rates of Bd exposure. Furthermore, these results suggest that although the adaptive immune system may be activated during Bd infections in some species, the capacity for a robust and protective adaptive response appears limited, which may be associated with Bd-induced suppression (discussed below).

\section{HOT TOPICS: STRESS, IMMUNOSUPPRESSION AND IMMUNOPATHOLOGY IN CHYTRIDIOMYCOSIS}

\section{Limited Evidence That Stress Predisposes Hosts to Chytridiomycosis via Corticosterone Responses}

There is no evidence to suggest that immunosuppression is necessary to predispose amphibians to chytridiomycosis epizootics, particularly with numerous observations of disease emergence in abundant species in undisturbed naïve localities (3, 163, 183). Furthermore, signs indicative of generalized 
immunosuppression, such as secondary bacterial infections, appear to be largely lacking $(8,48,88)$. However, stress-induced immunosuppression may play a role particularly in the infection of more resistant individuals and species [reviewed in (30)]. The extent to which environmental stressors and corticosterone mediate chytridiomycosis and its effects on amphibians is currently unclear. Environmental stressors (poor nutritional status, high densities and exposure to predator cues) have been putatively linked with elevated corticosterone and reduced immune capacity in some tadpole studies $(184,185)$, although it is unknown whether corticosterone is a direct mediator of these effects. Elevations in corticosteroids have been demonstrated to have a range of detrimental effects on the immune system of frogs, including inhibiting the humoral response, and reducing both numbers and viability of circulating lymphocytes [reviewed in (30)]. Indeed, exogenous application of corticosterone was found to increase $\mathrm{Bd}$ infection abundance in adult amphibians $(105,186)$, but only had sublethal effects on tadpoles (187). Gabor et al. (188) inhibited corticosterone synthesis (using metyrapone) and found that this did not prevent $\mathrm{Bd}$-associated reductions in mass, although it did increase Bd loads. They concluded that the adverse effects of $\mathrm{Bd}$ on growth were not mediated by corticosterone.

In the field, non-invasive measures of corticosterone in free-living populations of tadpoles revealed that corticosterone levels correlated both with Bd infection and altitude, and that infections with a more virulent strain of Bd (BdGPL) led to higher corticosterone release $(189,190)$. Measuring urinary corticosterone, Graham et al. (191) and Kindermann et al. (192) similarly found higher levels in infected frogs as well as frog populations at higher altitudes. Furthermore, Peterson et al. (165) measured plasma corticosterone and found that diseased frogs (showing clinical signs of chytridiomycosis) demonstrated higher corticosterone levels than subclinically infected frogs. Thus, from current evidence it appears that elevated corticosterone correlates with infection in situ, and both predisposes to chytridiomycosis, and is a result of infection. However, the link between putative environmental stressors and elevated corticosterone is less robust, and elevated corticosterone does not appear to mediate the sublethal effects of chytridiomycosis (growth and mass).

\section{Batrachochytrium dendrobatidis Suppresses Lymphocyte Responses in Susceptible Individuals}

Throughout this review, we have synthesized the results of numerous studies and highlighted the lack of a generally robust and protective immune response to Bd infection. We considered the epidemiology, general degree of inflammation, as well as markers of the innate immune response during early infection stages, and the adaptive immune response during late infection stages. This observed apparent lack of immune response may be the result of either (1) the failure of the host to recognize $\mathrm{Bd}$ as a pathogen, through low inherent antigenicity (possibly due to intracellular localization), immunoevasion, or masking antigens, or (2) Bd-induced immunosuppression or downregulation of key immune responses necessary for a protective immune response (145). Both of these mechanisms may occur in parallel in chytridiomycosis. For example, PRRs are generally not upregulated in early infection, suggesting a possible lack of pathogen recognition, whereas $\mathrm{T}$ cell responses appear actively suppressed or inhibited, as are complement-associated pathways.

Current evidence supports a specific role for Bd-induced immunosuppression, detected first via skin histopathology (77) and general immune function measures $(31,48)$, and corroborated via gene expression data $(18,98,119,120,151$, 153). Further experimental work has characterized at least one mechanism by which this might occur, via soluble Bd-secreted factors. Fites et al. (193) demonstrated that soluble factors released by $\mathrm{Bd}$ zoosporangia inhibited proliferation and/or caused apoptosis of T cells in vitro. For this work, they used in vitro immune experiments involving the proliferation of splenic lymphocytes (from X. laevis and R. pipiens) in culture. Interestingly, they found that macrophage phagocytosis was not similarly affected. Another study investigated apoptosis (via TUNEL and caspase assays) and found that programmed cell death was positively associated with infection load and morbidity (194). They speculated that apoptosis may thus be a pathogen virulence mechanism. In vivo studies also revealed immune inhibition activity associated with Bd supernatants by measuring delayed-type-hypersensitivity responses (33). RollinsSmith et al. (195) then went on to characterize two metabolites (methylthioadenosine and kynurenine) produced by Bd that are capable of inhibiting lymphocyte proliferation and survival in vitro.

\section{Late Stage Immunopathology Characterizes Infections in Susceptible Individuals}

Despite relative Bd-associated immunosuppression, several gene expression studies on a variety of amphibian species have demonstrated that susceptible individuals express both greater number and variety of dysregulated immune genes during late stage infections than more resistant individuals $(18,151$, 152). This negative correlation between extent of immune response and degree of phenotypic susceptibility suggests that susceptible individuals may mount massively dysregulated and non-protective immune responses. This immunopathology is likely associated with DAMPs induced late in infection as the pathogen damages skin cells in order to release subsequent generations of zoospores. Such a dysregulated response may rapidly disrupt cellular homeostatic mechanisms. Indeed, recent metabolomics findings support this hypothesis by demonstrating the significant depletion of the "immune nutrient factor," alphaketoglutarate and its associated metabolite glutamate in severely infected animals $(196,197)$. This metabolic dysregulation has carry-on effects on numerous other aspects of cell homeostasis, particularly cellular energy metabolism (alpha-ketoglutarate is a key intermediate of the Krebs cycle). Furthermore, in vitro and gene expression studies suggest massive disruption of homeostatic mechanisms involved in epithelial stability, water and ion transport and musculoskeletal functions in susceptible individuals $(18,41,98,120,151-153,176)$. Therefore, 
immunopathology within susceptible amphibian species may not only cause their immune responses to be ineffective at eliminating the pathogen, but it may contribute to host morbidity and mortality due to the extensive disruption of cellular homeostasis and consumption of energy resources.

\section{RECOMMENDATIONS FOR FUTURE WORK}

Despite two decades of research on chytridiomycosis, we still have only a limited understanding of the amphibian immune response to chytridiomycosis, and there is much to be discovered that may assist with disease mitigation. While continued support for existing approaches is essential, improving our capacity for amphibian immunological research will require: (1) the selection of an appropriate Bd-susceptible model species that could be bred to a MHC defined inbred strain (traditional amphibian models, Xenopus spp., are not sufficiently susceptible), (2) the development of a suite of taxon-specific affinity reagents (such as antibodies) for detection and imaging of pathogen-associated or host immune molecules of interest, and (3) the isolation or transgenic development of cell lines (including immune cells and skin explants) for in vitro functional assays.

A suite of conventional and emerging immunological methods from the fields of human and comparative immunology may be adapted for further study of amphibian chytridiomycosis. These methods enable the detection, quantification, isolation, functional evaluation, examination of signaling pathways, and localization of specific molecules of interest from homogenates, subcellular compartments (via biochemical fractionation), cells (separated by fluorescent-activated cell sorting [FACS] and flow cytometry), blood or tissues. For example, bioassays such as enzyme-linked immunosorbent assay (ELISA), measure the presence of various molecules (such as antibodies or antigens) via enzyme or ligand binding. Other bioassays may detect the presence and quantity of specific DNA (southern blot or qPCR), RNA (northern blot or RT-PCR), proteins (western blot) or their post-translational modifications (eastern blot). Flow cytometry enables the analysis of immune cells and their products, and cell sorting for proliferation and viability studies. Modern high-resolution imaging technologies include light microscopy combined with flow cytometry or standard labeling techniques with antibodies (immunohistochemistry and immunocytochemistry) or other stains, as well as electronmicroscopy.

Several preliminary exploratory systems biology studies have been reported in this review, for example, employing transcriptomics for gene expression and metabolomics for metabolite accumulation $(152,196)$. However, there are emerging approaches using high-throughput technologies such as next generation sequencing and mass spectrometry that still have unrealized potential for the study of amphibian chytridiomycosis (such as whole exome sequencing, proteomics, secretomics, and fluxomics). Importantly, further research using these emerging technologies would benefit from considering a broader temporal range in samples from experimental animals. In particular, experiments that compare the immune response in the very early infection period immediately post-exposure with the response later during infection would shed important light on initial susceptibility and within-host pathogen recognition and signaling dynamics. There is also potential for the use of microfluidics for single-cell-targeted approaches. Mass spectrometry and associated technologies [high performance liquid chromatography (HPLC) and nuclear magnetic resonance (NMR)] permit the high-throughput separation, identification and quantification of molecules of interest in a mixture. Combination techniques may permit high-dimensional data from these high-throughput technologies, such as the singlecell resolution of numerous cellular parameters over millions of cells via mass cytometry. Chromosome conformation capture may permit the identification of regulatory elements for immune genes of interest, and transgenic technologies may enable improved functional validation of the role of such genes and their translated protein products. These approaches include gene knock-in and knock-out on the pathogen and other organism cell lines (such as host immune cells), and include gene silencing (RNA interference), lentivectors, transposons and CRISPR/Cas9 genome editing. Indeed, some of these approaches may be used to advance therapeutic outcomes also. For example, recombinant $\mathrm{Bd}$ proteins or $\mathrm{Bd}$ genes introduced via vector may improve results in immunization trials compared with techniques already tried.

\section{CONCLUSIONS}

In summary, we have provided an overview of the major aspects of the amphibian host immune response to chytridiomycosis, and how they differ from an expected efficacious immune response. Importantly, we highlighted an observed discord between the extent and efficacy of the response to chytridiomycosis comparing resistant and susceptible individuals. These findings suggest that resistant individuals likely possess more effective constitutive defenses (such as AMPs and symbiotic bacteria), and/or may mount a more effective innate immune response early in infection, combined with avoiding Bd-induced immunosuppression of their adaptive responses. Conversely, constitutive and innate defenses of individuals that succumb to chytridiomycosis are likely limited in their overall efficacy. Although their late-stage immune response may be characterized by exacerbated immune gene transcription, these responses likely constitute immunopathology, and may be ineffective due to pathogen-suppression of lymphocyte pathways. Indeed, severe immune dysregulation may contribute to a mortality outcome. Hence a combination of factors likely contributes to amphibian susceptibility to chytridiomycosis, rather than the presence or absence of any one immune mechanism or gene. This is particularly important when comparing potential factors conferring resistance or tolerance between distantly related amphibian taxa.

Our review has highlighted numerous gaps in current knowledge, particularly concerning: (1) mechanisms of initial pathogen detection and possible immunoevasion by $\mathrm{Bd},(2)$ degree of activation and efficacy of the innate immune response, 
(3) the unexpected absence of innate leukocyte infiltration, (4) the relative importance of $\mathrm{B}$ and $\mathrm{T}$ cell responses for pathogen clearance, (5) the capacity and extent of immunological memory, (6) specific mechanisms of pathogen-induced immunosuppression, and (7) the role of immunopathology in pathogenesis. These aspects would benefit from further empirical study using the techniques we have discussed above. This also leaves us with an unanswered question for amphibian conservation management: can we manipulate the immune machinery of the host to improve resistance or tolerance both within individuals (immunization), and across populations through generations (evolution or assisted selection)? It is important to recognize that management approaches should be considered on two time-scales; (1) securing species in the short-term, and (2) developing long-term sustainable solutions (12). As we have reported earlier in this review, evidence is emerging that evolution of resistance and tolerance may be leading to recovery of some affected frog populations and communities (15). There is, as yet, limited proof of concept for strategies that might accelerate these evolutionary processes. However, immunological research remains a promising avenue

\section{REFERENCES}

1. Martel A, Blooi M, Adriaensen C, Van Rooij P, Beukema W, Fisher $\mathrm{MC}$, et al. Recent introduction of a chytrid fungus endangers Western Palearctic salamanders. Science (2014) 346:630-1. doi: 10.1126/science.12 58268

2. O'Hanlon SJ, Rieux A, Farrer RA, Rosa GM, Waldman B, Bataille A, et al. Recent Asian origin of chytrid fungi causing global amphibian declines. Science (2018) 360:621-7. doi: 10.1126/science.aar1965

3. Berger L, Speare R, Daszak P, Green DE, Cunningham AA, Goggin CL, et al. Chytridiomycosis causes amphibian mortality associated with population declines in the rain forests of Australia and Central America. Proc Natl Acad Sci USA. (1998) 95:9031-6. doi: 10.1073/pnas.95.15.9031

4. Longcore JE, Pessier AP, Nichols DK. Batrachochytrium dendrobatidis gen. et sp nov, a chytrid pathogenic to amphibians. Mycologia (1999) 91:219-27. doi: $10.2307 / 3761366$

5. Martel A, Spitzen-Van Der Sluijs A, Blooi M, Bert W, Ducatelle R, Fisher MC, et al. Batrachochytrium salamandrivorans sp. nov causes lethal chytridiomycosis in amphibians. Proc Natl Acad Sci USA. (2013) 110:153259. doi: 10.1073/pnas.1307356110

6. Fisher MC, Garner TWJ, Walker SF. Global emergence of Batrachochytrium dendrobatidis and amphibian chytridiomycosis in space, time, and host. Ann Rev Microbiol. (2009) 63:291-310. doi: 10.1146/annurev.micro.091208.073435

7. Skerratt LF, Berger L, Speare R, Cashins S, McDonald KR, Phillott $\mathrm{AD}$, et al. Spread of chytridiomycosis has caused the rapid global decline and extinction of frogs. EcoHealth (2007) 4:125-34. doi: 10.1007/s10393-007-0093-5

8. Berger L, Roberts AA, Voyles J, Longcore JE, Murray KA, Skerratt LF. History and recent progress on chytridiomycosis in amphibians. Fungal Ecol. (2016) 19:89-99. doi: 10.1016/j.funeco.2015.09.007

9. Lips KR. Overview of chytrid emergence and impacts on amphibians. Phil Trans R Soc Biol Sci. (2016) 371:20150465. doi: 10.1098/rstb.2015.0465

10. Scheele BC, Skerratt LF, Grogan LF, Hunter DA, Clemann N, McFadden M, et al. After the epidemic: ongoing declines, stabilizations and recoveries in amphibians afflicted by chytridiomycosis. Biol Conserv. (2017) 206:37-46. doi: 10.1016/j.biocon.2016.12.010

11. Van Rooij P, Martel A, Haesebrouck F, Pasmans F. Amphibian chytridiomycosis: a review with focus on fungus-host interactions. Vet Res. (2015) 46:137. doi: 10.1186/s13567-015-0266-0 for amphibian conservation management, in light of the dramatic advances achieved in the human medical field in recent years.

\section{AUTHOR CONTRIBUTIONS}

LG reviewed the literature and wrote the first draft. All authors contributed to revisions of the manuscript drafts.

\section{FUNDING}

LG was supported by Australian Research Council (ARC) grants DP180101415 and LP110200240. JR was supported by grants from the National Institute of Allergy and Infectious Diseases (NIH/NIAID, R24-AI-059830) and from the National Science Foundation (IOS-1456213). LB was supported by ARC grants FT100100375, LP110200240, and DP120100811. LS was supported by the ARC grants LP110200240 and DP120100811. HM was supported by ARC grant DP180101415. The funders had no role in study design, data collection and analysis, decision to publish or preparation of the manuscript.

12. Scheele BC, Hunter DA, Grogan LF, Berger L, Kolby JE, McFadden MS, et al. Interventions for reducing extinction risk in chytridiomycosis-threatened amphibians. Conserv Biol. (2014) 28:1195-205. doi: 10.1111/cobi.12322

13. Skerratt LF, Berger L, Clemann N, Hunter DA, Marantelli G, Newell DA, et al. Priorities for management of chytridiomycosis in Australia: saving frogs from extinction. Wildlife Res. (2016) 43:105-20. doi: 10.1071/WR15071

14. Venesky MD, Mendelson JR, Sears BF, Stiling P, Rohr JR. Selecting for tolerance against pathogens and herbivores to enhance success of reintroduction and translocation. Conserv Biol. (2012) 26:586-92. doi: 10.1111/j.1523-1739.2012.01854.x

15. Voyles J, Woodhams DC, Saenz V, Byrne AQ, Perez R, Rios-Sotelo G, et al. Shifts in disease dynamics in a tropical amphibian assemblage are not due to pathogen attenuation. Science (2018) 359:1517-9. doi: 10.1126/science.aao4806

16. Newell DA, Goldingay RL, Brooks LO. Population recovery following decline in an endangered stream-breeding frog (Mixophyes fleayi) from subtropical Australia. PLoS ONE (2013) 8:e58559. doi: 10.1371/journal.pone.0058559

17. Bataille A, Cashins SD, Grogan L, Skerratt LF, Hunter D, McFadden $\mathrm{M}$, et al. Susceptibility of amphibians to chytridiomycosis is associated with MHC class II conformation. Proc R Soc B Biol Sci. 282:20143127. doi: $10.1098 /$ rspb.2014.3127

18. Grogan LF, Cashins SD, Skerratt LF, Berger L, McFadden MS, Harlow P, et al. Evolution of resistance to chytridiomycosis is associated with a robust early immune response. Mol Ecol (2018) 27:919-34. doi: 10.1111/mec.14493

19. Kosch TA, Bataille A, Didinger C, Eimes JA, Rodríguez-Brenes S, Ryan MJ, et al. Major histocompatibility complex selection dynamics in pathogeninfected túngara frog (Physalaemus pustulosus) populations. Biol Lett. (2016) 12:20160345. doi: 10.1098/rsbl.2016.0345

20. Savage AE, Zamudio KR. MHC genotypes associate with resistance to a frog-killing fungus. Proc Natl Acad Sci USA. (2011) 108:16705-10. doi: $10.1073 /$ pnas. 1106893108

21. Savage AE, Zamudio KR. Adaptive tolerance to a pathogenic fungus drives major histocompatibility complex evolution in natural amphibian populations. Proc $R$ Soc B Biol Sci. 283:20153115. doi: $10.1098 / \mathrm{rspb} .2015 .3115$

22. Grogan LF, Phillott AD, Scheele BC, Berger L, Cashins SD, Bell SC, et al. Endemicity of chytridiomycosis features pathogen overdispersion. J Animal Ecol. (2016) 85:806-16. doi: 10.1111/1365-2656.12500

23. Phillott AD, Grogan LF, Cashins SD, McDonald KR, Berger L, Skerratt LF. Chytridiomycosis and seasonal mortality of tropical stream-associated frogs 
15 years after introduction of Batrachochytrium dendrobatidis. Conserv Biol. (2013) 27:1058-68. doi: 10.1111/cobi.12073

24. Scheele BC, Hunter DA, Brannelly LA, Skerratt LF, Driscoll DA. Reservoirhost amplification of disease impact in an endangered amphibian. Conserv Biol. (2017) 31:592-600. doi: 10.1111/cobi.12830

25. Scheele BC, Hunter DA, Skerratt LF, Brannelly LA, Driscoll DA. Low impact of chytridiomycosis on frog recruitment enables persistence in refuges despite high adult mortality. Biol Conserv. (2015) 182:36-43. doi: 10.1016/j.biocon.2014.11.032

26. Scheele BC, Hunter DA, Banks SC, Pierson JC, Skerratt LF, Webb $\mathrm{R}$, et al. High adult mortality in disease-challenged frog populations increases vulnerability to drought. J Anim Ecol. (2016) 85:1453-60. doi: 10.1111/1365-2656.12569

27. Brannelly LA, Hunter DA, Skerratt LF, Scheele BC, Lenger D, McFadden MS, et al. Chytrid infection and post-release fitness in the reintroduction of an endangered alpine tree frog. Anim Conserv. (2016) 19:153-62. doi: 10.1111/acv.12230

28. Stockwell MP, Clulow S, Clulow J, Mahony M. The impact of the amphibian chytrid fungus Batrachochytrium dendrobatidis on a green and golden bell frog Litoria aurea reintroduction program at the hunter wetlands Centre Australia in the Hunter Region of NSW. Australian Zoologist (2008) 34:37986. doi: 10.7882/AZ.2008.015

29. Rollins-Smith LA. The role of amphibian antimicrobial peptides in protection of amphibians from pathogens linked to global amphibian declines. Biochim Biophys Acta (2009) 1788:1593-9. doi: 10.1016/j.bbamem.2009.03.008

30. Rollins-Smith LA. Amphibian immunity-stress, disease, and climate change. Dev Compar Immunol. (2017) 66:111-9. doi: 10.1016/j.dci.2016.07.002

31. Rollins-Smith LA, Ramsey JP, Reinert LK, Woodhams DC, Livo LJ, Carey C. Immune defenses of Xenopus laevis against Batrachochytrium dendrobatidis. Front. Biosci. Scholar (2009) 1S:68-91. doi: 10.2741/s8

32. Walke JB, Belden LK. Harnessing the microbiome to prevent fungal infections: lessons from amphibians. PLoS Pathogens (2016) 12:e1005796. doi: 10.1371/journal.ppat.1005796

33. Fites SJ, Reinert LK, Chappell TM, Rollins-Smith LA. Inhibition of local immune responses by the frog-killing fungus Batrachochytrium dendrobatidis. Infect Immunity (2014) 82:4698-706. doi: 10.1128/IAI.02231-14

34. Fu M, Waldman B. Major histocompatibility complex variation and the evolution of resistance to amphibian chytridiomycosis. Immunogenetics (2017) 69:529-36. doi: 10.1007/s00251-017-1008-4

35. Murphy KP. Janeway's Immunobiology, 8th edn (2012). New York, NY: Garland Science.

36. Barr DJS. Chapter 5: Chytridiomycota. In: McLaughlin DJ, McLaughlin EG, Lemke PA, editors. The Mycota, A comprehesive treatise on fungi as experimental systems for basic and applied research, VII Systematics and Evolution, Part A. New York, NY: Springer-Verlag (2001) p. 93-112. doi: 10.1007/978-3-662-10376-0_5

37. Berger L, Hyatt AD, Speare R, Longcore JE. Life cycle stages of the amphibian chytrid Batrachochytrium dendrobatidis. Dis Aquat Organisms (2005) 68:5163. doi: 10.3354/dao068051

38. Voyles J, Johnson LR, Briggs CJ, Cashins SD, Alford RA, Berger L, et al. Temperature alters reproductive life history patterns in Batrachochytrium dendrobatidis, a lethal pathogen associated with the global loss of amphibians. Ecol Evol. (2012) 2:2241-9. doi: 10.1002/ece3.334

39. Woodhams DC, Alford RA, Briggs CJ, Johnson M, Rollins-Smith LA. Lifehistory trade-offs influence disease in changing climates: strategies of an amphibian pathogen. Ecology (2008) 89:1627-39. doi: 10.1890/06-1842.1

40. Berger L, Longcore JE, Speare R, Hyatt A, Skerratt LF. Chapter 2: fungal diseases in amphibians. In: Heatwole H, Wilkinson JW, editors. Amphibian Biology, Volume 8: Amphibian Decline: Disease, Parasites, Maladies, and Pollution. Chipping Norton, NSW: Surrey Beatty and Sons (2009). p. 29883052 .

41. Voyles J, Young S, Berger L, Campbell C, Voyles WF, Dinudom A, et al. Pathogenesis of chytridiomycosis, a cause of catastrophic amphibian declines. Science (2009) 326:582-5. doi: 10.1126/science.1176765

42. Blaustein AR, Romansic JM, Scheessele EA, Han BA, Pessier AP, Longcore JE. Interspecific variation in susceptibility of frog tadpoles to the pathogenic fungus Batrachochytrium dendrobatidis. Conserv Biol. (2005) 19:1460-8. doi: 10.1111/j.1523-1739.2005.00195.x

43. Marantelli G, Berger L, Speare R, Keegan L. Distribution of the amphibian chytrid Batrachochytrium dendrobatidis and keratin during tadpole development. Pacific Conserv Biol. (2004) 10:173-9. doi: 10.1071/PC 040173

44. McMahon TA, Rohr JR. Transition of Chytrid fungus infection from mouthparts to hind limbs during amphibian metamorphosis. EcoHealth (2015) 12:188-93. doi: 10.1007/s10393-014-0989-9

45. Rachowicz LJ, Vredenburg VT. Transmission of Batrachochytrium dendrobatidis within and between amphibian life stages. Dis Aquat Organisms (2004) 61:75-83. doi: 10.3354/dao061075

46. Robert J, Ohta Y. Comparative and developmental study of the immune system in xenopus. Dev Dynamics (2009) 238:1249-70. doi: $10.1002 /$ dvdy.21891

47. Du Pasquier L, Schwager J, Flajnik MF. The immune system of Xenopus. Ann Rev Immunol. (1989) 7:251-75. doi: 10.1146/annurev.iy.07.040189.001343

48. Young S, Whitehorn P, Berger L, Skerratt LF, Speare R, Garland S, et al. Defects in host immune function in tree frogs with Chronic Chytridiomycosis. PLoS ONE (2014) 9:e107284. doi: 10.1371/journal.pone.0107284

49. Flajnik MF. Comparative analyses of immunoglobulin genes: surprises and portents. Nat Rev Immunol. (2002) 2:688-98. doi: 10.1038/nri889

50. Marr S, Morales H, Bottaro A, Cooper M, Flajnik M, Robert J. Localization and differential expression of activation-induced cytidine deaminase in the amphibian Xenopus upon antigen stimulation and during early development. J Immunol. (2007) 179:6783-9. doi: 10.4049/jimmunol.179.10.6783

51. Ishii A, Kawasaki M, Matsumoto M, Tochinai S, Seya T. Phylogenetic and expression analysis of amphibian Xenopus Toll-like receptors. Immunogenetics (2007) 59:281-93. doi: 10.1007/s00251-007-0193-y

52. Fujita T, Endo Y, Nonaka M. Primitive complement system recognition and activation. Mol Immunol. (2004) 41:103-11. doi: 10.1016/j.molimm.2004.03.026

53. Du Pasquier L, Robert J, Courtet M, Mußmann R. B-cell development in the amphibian Xenopus. Immunol Rev. (2000) 175:201-13. doi: 10.1111/j.1600-065X.2000.imr017501.x

54. Hsu E. Mutation, selection, and memory in B lymphocytes of exothermic vertebrates. Immunol Rev. (1998) 162:25-36. doi: 10.1111/j.1600-065X.1998.tb01426.x

55. Wilson M, Hsu E, Marcuz A, Courtet M, Du Pasquier L, Steinberg C. What limits affinity maturation of antibodies in Xenopus-the rate of somatic mutation or the ability to select mutants? EMBO J. (1992) 11:4337-47. doi: 10.1002/j.1460-2075.1992.tb05533.x

56. Neely HR, Guo J, Flowers EM, Criscitiello MF, Flajnik MF. "Double-duty" conventional dendritic cells in the amphibian Xenopus as the prototype for antigen presentation to B cells. Eur J Immunol. (2018) 48:430-40. doi: 10.1002/eji.201747260

57. Robert J. Frog's DCs have it all in one. Eur J Immunol. (2018) 48:415-8. doi: 10.1002/eji.201747459

58. Li J, Barreda DR, Zhang YA, Boshra H, Gelman AE, LaPatra S, et al. B lymphocytes from early vertebrates have potent phagocytic and microbicidal abilities. Nat Immunol. (2006) 7:1116-24. doi: 10.1038/ni1389

59. Ohta Y, Flajnik M. IgD, like IgM, is a primordial immunoglobulin class perpetuated in most jawed vertebrates. Proc Natl Acad Sci USA. (2006) 103:10723-8. doi: 10.1073/pnas.0601407103

60. Zhao YF, Pan-Hammarstrom Q, Yu SY, Wertz N, Zhang XF, Li N, et al. Identification of IgF, a hinge-region-containing Ig class, and IgD in Xenopus tropicalis. Proc Natl Acad Sci USA. (2006) 103:12087-92. doi: $10.1073 /$ pnas.0600291103

61. Colombo BM, Scalvenzi T, Benlamara S, Pollet N. Microbiota and mucosal immunity in amphibians. Front Immunol. (2015) 6:111. doi: 10.3389/fimmu.2015.00111

62. Robert J, Gantress J, Rau L, Bell A, Cohen N. Minor histocompatibility antigen-specific MHC-restricted CD8 T cell responses elicited by heat shock proteins. J Immunol. (2002) 168:1697-703. doi: 10.4049/jimmunol.168.4.1697

63. Maniero GD, Robert J. Phylogenetic conservation of gp96-mediated antigen-specific cellular immunity: new evidence from adoptive 
cell transfer in xenopus. Transplantation (2004) 78:1415-21. doi: 10.1097/01.TP.0000140846.73210.91

64. Edholm E-S, Banach M, Hyoe Rhoo K, Pavelka MS, Robert J. Distinct MHC class I-like interacting invariant $\mathrm{T}$ cell lineage at the forefront of mycobacterial immunity uncovered in Xenopus. Proc Natl Acad Sci USA. (2018) 115:E4023-31. doi: 10.1073/pnas.1722129115

65. Edholm E-S, Goyos A, Taran J, De Jesús Andino F, Ohta Y, Robert J. Unusual evolutionary conservation and further species-specific adaptations of a large family of Nonclassical MHC class Ib genes across different degrees of genome ploidy in the amphibian subfamily Xenopodinae. Immunogenetics (2014) 66:411-26. doi: 10.1007/s00251-014-0774-5

66. Goyos A, Sowa J, Ohta Y, Robert J. Remarkable conservation of distinct nonclassical MHC class I lineages in divergent amphibian species. J Immunol. (2011) 186:372-81. doi: 10.4049/jimmunol.1001467

67. Edholm E-S, Banach M, Robert J. Evolution of innate-like T cells and their selection by MHC class I-like molecules. Immunogenetics (2016) 68:525-36. doi: 10.1007/s00251-016-0929-7

68. Rollins-Smith LA. Metamorphosis and the amphibian immune system. Immunol Rev. (1998) 166:221-30. doi: 10.1111/j.1600-065X.1998.tb01265.x

69. Rollins-Smith LA, Ramsey JP, Pask JD, Reinert LK, Woodhams DC. Amphibian immune defenses against chytridiomycosis: impacts of changing environments. Integr Compar Biol. (2011) 51:552-62. doi: 10.1093/icb/icr095

70. Flajnik MF, Hsu E, Kaufman JF, Dupasquier L. Changes in the immune system during metamorphosis of Xenopus. Immunol Today (1987) 8:58-64. doi: 10.1016/0167-5699(87)90240-4

71. Ortiz-Santaliestra ME, Rittenhouse TAG, Cary TL, Karasov WH. Interspecific and postmetamorphic variation in susceptibility of three North American anurans to Batrachochytrium dendrobatidis. J Herpetol. (2013) 47:286-92. doi: 10.1670/11-134

72. Fox H. The structure of the integument. In: Heatwole $\mathrm{H}$ and Barthalmus GT. Amphibian Biology-Volume 1: The Integument. Chipping Norton, NSW: Surrey Beatty and Sons (1994).

73. Cramp RL, McPhee RK, Meyer EA, Ohmer ME, Franklin CE. First line of defence: The role of sloughing in the regulation of cutaneous microbes in frogs. Conserv Physiol. (2014) 2:cou012. doi: 10.1093/conphys/cou012

74. Carrillo-Farga J, Castell A, Perez A, Rondan A. Langerhans-like cells in amphibian epidermis. J Anat. (1990) 172:39-45.

75. Du Pasquier L, Flajnik MF. Expression of MHC class II antigens during xenopus development. Dev Immunol. (1990) 1:85-95. doi: 10.1155/1990/67913

76. Mescher AL, Wolf WL, Ashley Moseman E, Hartman B, Harrison C, Nguyen E, et al. Cells of cutaneous immunity in Xenopus: studies during larval development and limb regeneration. Dev Compar Immunol. (2007) 31:38393. doi: 10.1016/j.dci.2006.07.001

77. Berger L, Speare R, Skerratt LF. Distribution of Batrachochytrium dendrobatidis and pathology in the skin of green tree frogs Litoria caerulea with severe chytridiomycosis. Dis Aquat Org. (2005) 68:65-70. doi: $10.3354 /$ dao 068065

78. Duellman WE, Trueb L. Biology of Amphibians. Baltimore, MD: The Johns Hopkins University Press (1994).

79. Schwinger G, Zanger K, Greven H. Structural and mechanical aspects of the skin of Bufo marinus (Anura, Amphibia). Tissue Cell (2001) 33:541-7. doi: 10.1054/tice.2001.0208

80. Garmyn A, van Rooij P, Pasmans F, Hellebuyck T, van den Broeck W, Haesebrouck F, et al. Waterfowl: Potential environmental reservoirs of the chytrid fungus Batrachochytrium dendrobatidis. PLoS ONE (2012) 7:e35038. doi: 10.1371/journal.pone.0035038

81. Moss AS, Reddy NS, Dortaj IM, Francisco MJS. Chemotaxis of the amphibian pathogen Batrachochytrium dendrobatidis and its response to a variety of attractants. Mycologia (2008) 100:1-5. doi: 10.1080/15572536.2008.11832493

82. Meyer EA, Cramp RL, Bernal MH, Franklin CE. Changes in cutaneous microbial abundance with sloughing: possible implications for infection and disease in amphibians. Dis Aquat Org. (2012) 101:235-42. doi: $10.3354 /$ dao 02523

83. Davidson EW, Parris M, Collins JP, Longgore JE, Pessier AP, Brunner J. Pathogenicity and transmission of chytridiomycosis in tiger salamanders (Ambystoma tigrinum). Copeia (2003) 601-7. doi: 10.1643/CP-02-120R1
84. Ohmer MEB, Cramp RL, White CR, Franklin CE. Skin sloughing rate increases with chytrid fungus infection load in a susceptible amphibian. Funct Ecol. (2015) 29:674-82. doi: 10.1111/1365-2435.12370

85. Ohmer MEB, Cramp RL, Russo CJM, White CR, Franklin CE. Skin sloughing in susceptible and resistant amphibians regulates infection with a fungal pathogen. Sci Rep. (2017) 7:3529. doi: 10.1038/s41598-01703605-z

86. Boltaña S, Rey S, Roher N, Vargas R, Huerta M, Huntingford FA, et al. Behavioural fever is a synergic signal amplifying the innate immune response. Proc R Soc B Biol Sci. 280:20131381. doi: 10.1098/rspb. 2013.1381

87. Richards-Zawacki CL. Thermoregulatory behaviour affects prevalence of chytrid fungal infection in a wild population of Panamanian golden frogs. Proc R Soc B Biol Sci. (2010) 277:519-28. doi: 10.1098/rspb.2009.1656

88. Berger L, Speare R, Hines HB, Marantelli G, Hyatt AD, McDonald $\mathrm{KR}$, et al. Effect of season and temperature on mortality in amphibians due to chytridiomycosis. Austr Veter J. (2004) 82:434-9. doi: 10.1111/j.1751-0813.2004.tb11137.x

89. Ramsey JP, Reinert LK, Harper LK, Woodhams DC, Rollins-Smith LA. Immune defenses against Batrachochytrium dendrobatidis, a fungus linked to global amphibian declines, in the South African clawed frog, Xenopus laevis. Infect Immunity (2010) 78:3981-92. doi: 10.1128/IAI.00402-10

90. Bouvet JP, Fischetti VA. Diversity of antibody-mediated immunity at the mucosal barrier. Infect Immunity (1999) 67:2687-91.

91. Du Pasquier L. Antibody diversity in lower vertebrates - why is it so restricted? Nature (1982) 296:311-3. doi: 10.1038/296311a0

92. Vas J, Grönwall C, Silverman G. Fundamental roles of the innate-like repertoire of natural antibodies in immune homeostasis. Front Immunol. (2013) 4:4. doi: 10.3389/fimmu.2013.00004

93. Ostrovsky DS, Snyder JA, Iwata T, Izaka KI, Maglott DS, Nace GW. Frog lysozyme. I Its identification, occurrence as isozymes, and quantitative distribution in tissues of the leopard frog, Rana pipiens. J Exp Zool. (1976) 195:279-90. doi: 10.1002/jez.1401950213

94. Zhao Y, Jin Y, Lee WH, Zhang Y. Purification of a lysozyme from skin secretions of Bufo andrewsi. Compar Biochem Physiol C Toxicol Pharmacol. (2006) 142:46-52. doi: 10.1016/j.cbpc.2005.10.001

95. Anil S, Samaranayake LP. Impact of lysozyme and lactoferrin on oral Candida isolates exposed to polyene antimycotics and fluconazole. Oral Dis. (2002) 8:199-206. doi: 10.1034/j.1601-0825.2002.01818.x

96. Woods CM, Hooper DN, Ooi EH, Tan LW, Carney AS. Human lysozyme has fungicidal activity against nasal fungi. Am J Rhinol Allergy (2011) 25:236-40. doi: 10.2500/ajra.2011.25.3631

97. Rollins-Smith LA, Woodhams DC. Chapter 4: Amphibian immunity staying in tune with the environment. In: Demas GE, Nelson RJ, editors. Ecoimmunology. New York, NY: Oxford University Press (2012). pp. 92-143.

98. Rosenblum EB, Poorten TJ, Settles M, Murdoch GK, Robert J, Maddox N, et al. Genome-wide transcriptional response of Silurana (Xenopus) tropicalis to infection with the deadly chytrid fungus. PLoS ONE (2009) 4:e6494. doi: 10.1371 /journal.pone. 0006494

99. Clarke BT. The natural history of amphibian skin secretions, their normal functioning and potential medical applications. Biol Rev. (1997) 72:365-79. doi: $10.1017 /$ S0006323197005045

100. Nicolas P, Mor A. Peptides as weapons against microorganisms in the chemical defense system of vertebrates. Ann Rev Microbiol. (1995) 49:277304. doi: 10.1146/annurev.mi.49.100195.001425

101. Conlon JM, Abraham B, Sonnevend A, Jouenne T, Cosette P, Leprince J, et al. Purification and characterization of antimicrobial peptides from the skin secretions of the carpenter frog Rana virgatipes (Ranidae, Aquarana). Regul Peptides (2005) 131:38-45. doi: 10.1016/j.regpep.2005.06.003

102. Conlon JM, Sonnevend A, Patel M, Al-Dhaheri K, Nielsen PF, Kolodziejek J, et al. A family of brevinin-2 peptides with potent activity against Pseudomonas aeruginosa from the skin of the Hokkaido frog, Rana pirica. Regul Peptides (2004) 118:135-41. doi: 10.1016/j.regpep.2003.12.003

103. King JD, Al-Ghaferi N, Abraham B, Sonnevend A, Leprince J, Nielsen $\mathrm{PF}$, et al. Pentadactylin: an antimicrobial peptide from the skin secretions of the South American bullfrog Leptodactylus pentadactylus. Compar Biochem Physiol C Toxicol Pharmacol. (2005) 141:393-7. doi: $10.1016 /$ j.cbpc.2005.09.002 
104. Mangoni ML, Miele R, Renda TG, Barra D, Simmaco M. The synthesis of antimicrobial peptides in the skin of Rana esculenta is stimulated by microorganisms. FASEB J. (2001) 15:1431-2. doi: 10.1096/fj.00-0695fje

105. Tatiersky L, Rollins-Smith LA, Lu R, Jardine C, Barker IK, Clark ME, et al. Effect of glucocorticoids on expression of cutaneous antimicrobial peptides in northern leopard frogs (Lithobates pipiens). BMC Veter Res. (2015) 11:191. doi: 10.1186/s12917-015-0506-6

106. Pask JD, Woodhams DC, Rollins-Smith LA. The ebb and flow of antimicrobial skin peptides defends northern leopard frogs (Rana pipiens) against chytridiomycosis. Glob Change Biol. (2012) 18:1231-8. doi: 10.1111/j.1365-2486.2011.02622.x

107. König E, Bininda-Emonds ORP, Shaw C. The diversity and evolution of anuran skin peptides. Peptides (2015) 63:96-117. doi: 10.1016/j.peptides.2014.11.003

108. Burkart D, Flechas SV, Vredenburg VT, Catenazzi A. Cutaneous bacteria, but not peptides, are associated with chytridiomycosis resistance in Peruvian marsupial frogs. Animal Conserv. (2017) 20:483-91. doi: 10.1111/acv.12352

109. Conlon JM. The contribution of skin antimicrobial peptides to the system of innate immunity in anurans. Cell Tiss Res. (2011) 343:201-12. doi: 10.1007/s00441-010-1014-4

110. Rollins-Smith LA, Woodhams DC, Reinert LK, Vredenburg VT, Briggs CJ, Nielsen PF, et al. Antimicrobial peptide defenses of the mountain yellowlegged frog (Rana muscosa). Dev Compar Immunol. (2006) 30:831-42. doi: 10.1016/j.dci.2005.10.005

111. Woodhams DC, Ardipradja K, Alford RA, Marantelli G, Reinert LK, RollinsSmith LA. Resistance to chytridiomycosis varies among amphibian species and is correlated with skin peptide defenses. Anim Conserv. (2007) 10:40917. doi: 10.1111/j.1469-1795.2007.00130.x

112. Woodhams DC, Rollins-Smith LA, Carey C, Reinert L, Tyler MJ, Alford RA. Population trends associated with skin peptide defenses against chytridiomycosis in Australian frogs. Oecologia (2006) 146:531-40. doi: 10.1007/s00442-005-0228-8

113. Woodhams DC, Voyles J, Lips KR, Carey C, Rollins-Smith LA. Predicted disease susceptibility in a Panamanian amphibian assemblage based on skin peptide defenses. J Wildlife Dis. (2006) 42:207-18. doi: 10.7589/0090-3558-42.2.207

114. Daum JM, Davis LR, Bigler L, Woodhams DC. Hybrid advantage in skin peptide immune defenses of water frogs (Pelophylax esculentus) at risk from emerging pathogens. Infect Genet Evol. (2012) 12:1854-64. doi: 10.1016/j.meegid.2012.07.024

115. Thekkiniath JC, Zabet-Moghaddam M, San Francisco SK, San Francisco MJ. A novel subtilisin-like serine protease of Batrachochytrium dendrobatidis is induced by thyroid hormone and degrades antimicrobial peptides. Fungal Biol. (2013) 117:451-61. doi: 10.1016/j.funbio.2013.05.002

116. Pask JD, Cary TL, Rollins-Smith LA. Skin peptides protect juvenile leopard frogs (Rana pipiens) against chytridiomycosis. J Exp Biol. (2013) 216:290816. doi: $10.1242 /$ jeb.084145

117. Woodhams DC, Bigler L, Marschang R. Tolerance of fungal infection in European water frogs exposed to Batrachochytrium dendrobatidis after experimental reduction of innate immune defenses. BMC Veter Res. (2012) 8:197. doi: 10.1186/1746-6148-8-197

118. Woodhams DC, Bell SC, Kenyon N, Alford RA, Rollins-Smith LA. Immune evasion or avoidance: fungal skin infection linked to reduced defence peptides in Australian green-eyed treefrogs, Litoria serrata. Fung Biol. (2012) 116:1203-11. doi: 10.1016/j.funbio.2012.10.005

119. Ribas L, Li MS, Doddington BJ, Robert J, Seidel JA, Simon Kroll J, et al. Expression profiling the temperature-dependent amphibian response to infection by Batrachochytrium dendrobatidis. PLoS ONE (2009) 4:e8408. doi: 10.1371/journal.pone.0008408

120. Rosenblum EB, Poorten TJ, Settles M, Murdoch GK. Only skin deep: shared genetic response to the deadly chytrid fungus in susceptible frog species. $\mathrm{Mol}$ Ecol. (2012) 21:3110-20. doi: 10.1111/j.1365-294X.2012.05481.x

121. Bates KA, Clare FC, O'Hanlon S, Bosch J, Brookes L, Hopkins K, et al. Amphibian chytridiomycosis outbreak dynamics are linked with host skin bacterial community structure. Nat Commun. (2018) 9:693. doi: 10.1038/s41467-018-02967-w

122. Austin RM. Chapter 25: Cutaneous microbial flora and antibiosis in Plethodon ventralis - Inferences for parental care in the Plethodontidae.
In: Bruce RC, Jaeger RG, Houck LD, editors. The Biology of Plethodontid Salamanders. New York, NY: Kluwer Academic/Plenum Publishers (2000). pp. 451-62. doi: 10.1007/978-1-4615-4255-1_25

123. Culp CE, Falkinham JO, Belden LK. Identification of the natural bacterial microflora on the skin of eastern newts, bullfrog tadpoles and redback salamanders. Herpetologica (2007) 63:66-71. doi: 10.1655/00180831(2007)63[66:IOTNBM]2.0.CO;2

124. Lam BA, Walton DB, Harris RN. Motile zoospores of batrachochytrium dendrobatidis move away from antifungal metabolites produced by amphibian skin bacteria. EcoHealth (2011) 8:36-45. doi: 10.1007/s10393-011-0689-7

125. Bell SC, Alford RA, Garland S, Padilla G, Thomas AD. Screening bacterial metabolites for inhibitory effects against Batrachochytrium dendrobatidis using a spectrophotometric assay. Dis Aquat Org. (2013) 103:77-85. doi: $10.3354 /$ dao02560

126. Harris RN, James TY, Lauer A, Simon MA, Patel A. Amphibian pathogen Batrachochytrium dendrobatidis is inhibited by the cutaneous bacteria of amphibian species. EcoHealth (2006) 3:53-6. doi: 10.1007/s10393-005-0009-1

127. Woodhams DC, LaBumbard BC, Barnhart KL, Becker MH, Bletz MC, Escobar LA, et al. Prodigiosin, violacein, and volatile organic compounds produced by widespread cutaneous bacteria of amphibians can inhibit two batrachochytrium fungal pathogens. Microb Ecol. (2018) 75:1049-62. doi: 10.1007/s00248-017-1095-7

128. Harris RN, Brucker RM, Walke JB, Becker MH, Schwantes CR, Flaherty DC, et al. Skin microbes on frogs prevent morbidity and mortality caused by a lethal skin fungus. ISME J. (2009) 3:818-24. doi: 10.1038/ismej.2009.27

129. Holden WM, Hanlon SM, Woodhams DC, Chappell TM, Wells HL, Glisson $\mathrm{SM}$, et al. Skin bacteria provide early protection for newly metamorphosed southern leopard frogs (Rana sphenocephala) against the frog-killing fungus, Batrachochytrium dendrobatidis. Biol Conserv. (2015) 187:91-102. doi: 10.1016/j.biocon.2015.04.007

130. Muletz CR, Myers JM, Domangue RJ, Herrick JB, Harris RN. Soil bioaugmentation with amphibian cutaneous bacteria protects amphibian hosts from infection by Batrachochytrium dendrobatidis. Biol Conserv. (2012) 152:119-26. doi: 10.1016/j.biocon.2012.03.022

131. Rebollar EA, Simonetti SJ, Shoemaker WR, Harris RN. Direct and indirect horizontal transmission of the antifungal probiotic bacterium Janthinobacterium lividum on green frog (Lithobates clamitans) tadpoles. Appl Environ Microbiol. (2016) 82:2457-66. doi: 10.1128/AEM.04147-15

132. Becker MH, Harris RN, Minbiole KP, Schwantes CR, Rollins-Smith LA, Reinert LK, et al. Towards a better understanding of the use of probiotics for preventing chytridiomycosis in Panamanian golden frogs. EcoHealth (2011) 8:501-6. doi: 10.1007/s10393-012-0743-0

133. Becker MH, Walke JB, Cikanek S, Savage AE, Mattheus N, Santiago CN, et al. Composition of symbiotic bacteria predicts survival in Panamanian golden frogs infected with a lethal fungus. Proc. Biol Sci. (2015) 282:20142881. doi: $10.1098 / \mathrm{rspb} .2014 .2881$

134. Lam BA, Walke JB, Vredenburg VT, Harris RN. Proportion of individuals with anti-Batrachochytrium dendrobatidis skin bacteria is associated with population persistence in the frog Rana muscosa. Biol Conserv. (2010) 143:529-31. doi: 10.1016/j.biocon.2009.11.015

135. Woodhams DC, Vredenburg VT, Simon MA, Billheimer D, Shakhtour B, Shyr Y, et al. Symbiotic bacteria contribute to innate immune defenses of the threatened mountain yellow-legged frog, Rana muscosa. Biol. Conserv. (2007) 138:390-8. doi: 10.1016/j.biocon.2007.05.004

136. Flechas SV, Sarmiento C, Cárdenas ME, Medina EM, Restrepo S, Amézquita A. Surviving chytridiomycosis: differential anti-Batrachochytrium dendrobatidis activity in bacterial isolates from three lowland species of Atelopus. PLoS ONE (2012) 7:44832. doi: 10.1371/journal.pone.00 44832

137. Holden WM, Reinert LK, Hanlon SM, Parris MJ, Rollins-Smith LA. Development of antimicrobial peptide defenses of southern leopard frogs, Rana sphenocephala, against the pathogenic chytrid fungus, Batrachochytrium dendrobatidis. Dev Compar Immunol. (2014) 48:65-75. doi: 10.1016/j.dci.2014.09.003

138. Myers JM, Ramsey JP, Blackman AL, Nichols AE, Minbiole KPC, Harris RN. Synergistic inhibition of the lethal fungal pathogen batrachochytrium 
dendrobatidis: the combined effect of symbiotic bacterial metabolites and antimicrobial peptides of the frog rana muscosa. J Chem Ecol. (2012) 38:95865. doi: 10.1007/s10886-012-0170-2

139. Piovia-Scott J, Rejmanek D, Woodhams DC, Worth SJ, Kenny H, McKenzie V, et al. Greater species richness of bacterial skin symbionts better suppresses the amphibian fungal pathogen Batrachochytrium dendrobatidis. Microb Ecol. (2017) 74:217-26. doi: 10.1007/s00248-0160916-4

140. Rebollar EA, Hughey MC, Medina D, Harris RN, Ibáñez R, Belden LK. Skin bacterial diversity of Panamanian frogs is associated with host susceptibility and presence of Batrachochytrium dendrobatidis. ISME J. (2016) 10:168295. doi: 10.1038 /ismej.2015.234

141. Bletz MC, Loudon AH, Becker MH, Bell SC, Woodhams DC, Minbiole KPC, et al. Mitigating amphibian chytridiomycosis with bioaugmentation: characteristics of effective probiotics and strategies for their selection and use. Ecol Lett. (2013) 16:807-20. doi: 10.1111/ele.12099

142. Rebollar EA, Antwis RE, Becker MH, Belden LK, Bletz MC, Brucker $\mathrm{RM}$, et al. Using "omics" and integrated multi-omics approaches to guide probiotic selection to mitigate chytridiomycosis and other emerging infectious diseases. Front Microbiol. (2016) 7:68. doi: $10.3389 /$ fmicb. 2016.00068

143. Greenspan SE, Longcore JE, Calhoun AJK. Host invasion by Batrachochytrium dendrobatidis: fungal and epidermal ultrastructure in model anurans. Dis Aquat Org. (2012) 100:201-10. doi: 10.3354/dao 02483

144. van Rooij P, Martel A, D'Herde K, Brutyn M, Croubels S, Ducatelle R, et al. Germ tube mediated invasion of Batrachochytrium dendrobatidis in Amphibian skin is host dependent. PLoS ONE (2012) 7:41481. doi: 10.1371/journal.pone.0041481

145. Chai LYA, Netea MG, Vonk AG, Kullberg BJ. Fungal strategies for overcoming host innate immune response. Med Mycol. (2009) 47:227-36. doi: 10.1080/13693780802209082

146. Plato A, Hardison SE, Brown GD. Pattern recognition receptors in antifungal immunity. Semin Immunopathol. (2015) 37:97-106. doi: $10.1007 / \mathrm{s} 00281-014-0462-4$

147. Woods JP. Knocking on the right door and making a comfortable home: Histoplasma capsulatum intracellular pathogenesis. Curr Opin Microbiol. (2003) 6:327-31. doi: 10.1016/S1369-5274(03)00080-8

148. Takeuchi O, Akira S. Pattern recognition receptors and inflammation. Cell (2010) 140:805-20. doi: 10.1016/j.cell.2010.01.022

149. Patin EC, Thompson A, Orr SJ. Pattern recognition receptors in fungal immunity. Semin Cell Dev Biol. (2018). doi: 10.1016/j.semcdb.2018.03.003. [Epub ahead of print].

150. Fitzgerald KA, Palsson-McDermott EM, Bowie AG, Jefferies CA, Mansell AS, Brady G, et al. Mal (MyD88-adapter-like) is required for Toll-like receptor-4 signal transduction. Nature (2001) 413:78. doi: 10.1038/35092578

151. Ellison AR, Savage AE, DiRenzo GV, Langhammer P, Lips KR, Zamudio KR. Fighting a losing battle: vigorous immune response countered by pathogen suppression of host defenses in the chytridiomycosis-susceptible frog Atelopus zeteki. G3 Genes Genomes Genetics (2014) 4:1275-89. doi: $10.1534 / \mathrm{g} 3.114 .010744$

152. Ellison AR, Tunstall T, Direnzo GV, Hughey MC, Rebollar EA, Belden LK, et al. More than skin deep: functional genomic basis for resistance to amphibian chytridiomycosis. Genome Biol Evol. (2014) 7:286-98. doi: $10.1093 /$ gbe/evu285

153. Poorten TJ, Rosenblum EB. Comparative study of host response to chytridiomycosis in a susceptible and a resistant toad species. Mol Ecol. (2016) 25:5663-79. doi: 10.1111/mec.13871

154. Cunha C, Carvalho A, Esposito A, Bistoni F, Romani L. DAMP signaling in fungal infections and diseases. Front Immunol. (2012) 3:286. doi: 10.3389 /fimmu.2012.00286

155. Brem F, Parris M. Epidermal trauma reduces the impact of Batrachochytrium dendrobatidis in Fowler's toads (Anaxyrus fowleri). Open Zool J. (2013) 6:1-7. doi: 10.2174/1874336601306010001

156. Speth C, Rambach G, Wurzner R, Lass-Florl C. Complement and fungal pathogens: an update. Mycoses (2008) 51:477-96. doi: 10.1111/j.1439-0507.2008.01597.x
157. Tam JCH, Bidgood SR, McEwan WA, James LC. Intracellular sensing of complement C3 activates cell autonomous immunity. Science (2014) 345:1256070. doi: 10.1126/science. 1256070

158. Ricklin D, Reis ES, Mastellos DC, Gros P, Lambris JD. Complement component C3-the "Swiss Army Knife" of innate immunity and host defense. Immunol Rev. (2016) 274:33-58. doi: 10.1111/imr.12500

159. McKnight BJ, Jurd RD. The compatibility of Xenopus antibody and homoiothermic complement. Dev Comparat Immunol. (1987) 11:585-93. doi: 10.1016/0145-305X(87)90047-4

160. Price SJ, Garner TWJ, Balloux F, Ruis C, Paszkiewicz KH, Moore K, et al. A de novo assembly of the common frog (Rana temporaria) transcriptome and comparison of transcription following exposure to Ranavirus and Batrachochytrium dendrobatidis. PLoS ONE (2015) 10:e0130500. doi: 10.1371/journal.pone. 0130500

161. Mao L, Zhang L, Li H, Chen W, Wang H, Wu S, et al. Pathogenic fungus Microsporum canis activates the NLRP3 Inflammasome. Infect Immunity (2014) 82:882-92. doi: 10.1128/IAI.01097-13

162. Pilla-Moffett D, Barber MF, Taylor GA, Coers J. Interferon-inducible GTPases in host resistance, inflammation and disease. J Mol Biol. (2016) 428:3495-513. doi: 10.1016/j.jmb.2016.04.032

163. Berger L, Speare R, Hyatt A. Chytrid fungi and amphibian declines: overview, implications and future directions. In: Campbell A, editor. Declines and Disappearances of Australian Frogs. Canberra, ACT: Environment Australia (1999) p. 23-33.

164. Davis AK, Keel MK, Ferreira A, Maerz JC. Effects of chytridiomycosis on circulating white blood cell distributions of bullfrog larvae (Rana catesbeiana). Compar Clin Pathol. (2010) 19:49-55. doi: 10.1007/s00580-009-0914-8

165. Peterson JD, Steffen JE, Reinert LK, Cobine PA, Appel A, Rollins-Smith L, et al. Host stress response is important for the pathogenesis of the deadly amphibian disease, chytridiomycosis, in Litoria caerulea. PLoS ONE (2013) 8:7. doi: 10.1371/journal.pone.0062146

166. Dhabhar FS, Miller AH, McEwen BS, Spencer RL. Stress-induced changes in blood leukocyte distribution: role of adrenal steroid hormones. J Immunol. (1996) 157:1638-44.

167. Nichols DK, Lamirande EW, Pessier AP, Longcore JE. Experimental transmission of cutaneous chytridiomycosis in dendrobatid frogs. J Wildlife Dis. (2001) 37:1-11. doi: 10.7589/0090-3558-37.1.1

168. Pessier AP, Nichols DK, Longcore JE, Fuller MS. Cutaneous chytridiomycosis in poison dart frogs (Dendrobates spp.) and White's tree frogs (Litoria caerulea). J Veterinary Diagn Investig. (1999) 11:194-9. doi: $10.1177 / 104063879901100219$

169. Gantress J, Maniero GD, Cohen N, Robert J. Development and characterization of a model system to study amphibian immune responses to iridoviruses. Virology (2003) 311:254-62. doi: 10.1016/S0042-6822(03)00151-X

170. Maniero GD, Morales H, Gantress J, Robert J. Generation of a longlasting, protective, and neutralizing antibody response to the ranavirus FV3 by the frog Xenopus. Dev Comp Immunol. (2006) 30:649-57. doi: 10.1016/j.dci.2005.09.007

171. Meyer D, Thomson G. How selection shapes variation of the human major histocompatibility complex: a review. Ann Hum Genet. (2001) 65:1-26. doi: 10.1046/j.1469-1809.2001.6510001.x

172. Teacher AGF, Garner TWJ, Nichols RA. Evidence for directional selection at a novel major histocompatibility class I marker in wild common frogs (Rana temporaria) exposed to a viral pathogen (Ranavirus). PLoS ONE (2009) 4:e4616. doi: 10.1371/journal.pone.0004616

173. Luquet E, Garner TW, Léna JP, Bruel C, Joly P, Lengagne T, et al. Genetic erosion in wild populations makes resistance to a pathogen more costly. Evolution (2012) 66:1942-52. doi: 10.1111/j.1558-5646.2011.01570.x

174. Bletz MC, Myers J, Woodhams DC, Rabemananjara FCE, Rakotonirina A, Weldon C, et al. Estimating herd immunity to amphibian chytridiomycosis in Madagascar based on the defensive function of amphibian skin bacteria. Front Microbiol. (2017) 8:1751. doi: 10.3389/fmicb.2017.01751

175. Antonovics J. Transmission dynamics: critical questions and challenges. Philos Trans R Soc Lond B Biol Sci. (2017) 372:20160087. doi: 10.1098/rstb.2016.0087 
176. Eskew EA, Shock BC, Ladouceur EEB, Keel K, Miller MR, Foley JE, et al. Gene expression differs in susceptible and resistant amphibians exposed to Batrachochytrium dendrobatidis. R Soc Open Sci. (2018) 5:170910. doi: 10.1098/rsos.170910

177. Kurtz J, Scharsack JP. Resistance is skin-deep: innate immunity may help amphibians to survive a deadly fungus. Anim Conserv. (2007) 10:422-4. doi: 10.1111/j.1469-1795.2007.00149.x

178. Robbins AH, Borden MD, Windmiller BS, Niezgoda M, Marcus LC, O'Brien SM, et al. Prevention of the spread of rabies to wildlife by oral vaccination of raccoons in Massachusetts. J Am Veter Med Assoc. (1998) 213:1407-12.

179. Stice MJ, Briggs CJ. Immunization is ineffective at preventing infection and mortality due to the amphibian chytrid fungus Batrachochytrium dendrobatidis. J Wildlife Dis. (2010) 46:70-7. doi: 10.7589/0090-355846.1.70

180. Cashins SD, Grogan LF, McFadden M, Hunter D, Harlow PS, Berger L, et al. Prior infection does not improve survival against the amphibian disease chytridiomycosis. PLoS ONE (2013) 8:e56747. doi: 10.1371/journal.pone.0056747

181. Murphy PJ, St.-Hilaire S, Corn PS. Temperature, hydric environment, and prior pathogen exposure alter the experimental severity of chytridiomycosis in boreal toads. Dis Aquat Organisms (2011) 95:31-42. doi: 10.3354/dao02336

182. McMahon TA, Sears BF, Venesky MD, Bessler SM, Brown JM, Deutsch $\mathrm{K}$, et al. Amphibians acquire resistance to live and dead fungus overcoming fungal immunosuppression. Nature (2014) 511:224-7. doi: 10.1038 /nature13491

183. Woodhams DC, Kilburn VL, Reinert LK, Voyles J, Medina D, Ibáñez R, et al. Chytridiomycosis and amphibian population declines continue to spread eastward in panama. EcoHealth (2008) 5:268-74. doi: 10.1007/s10393-008-0190-0

184. Reeve BC, Crespi EJ, Whipps CM, Brunner JL. Natural stressors and Ranavirus susceptibility in Larval Wood Frogs (Rana sylvatica). EcoHealth (2013) 10:190-200. doi: 10.1007/s10393-0130834-6

185. Venesky MD, Wilcoxen TE, Rensel MA, Rollins-Smith L, Kerby JL, Parris MJ. Dietary protein restriction impairs growth, immunity, and disease resistance in southern leopard frog tadpoles. Oecologia (2012) 169:23-31. doi: 10.1007/s00442-011-2171-1

186. Fonner CW, Patel SA, Boord SM, Venesky MD, Woodley SK. Effects of corticosterone on infection and disease in salamanders exposed to the amphibian fungal pathogen Batrachochytrium dendrobatidis. Dis Aquat Org. (2017) 123:159-71. doi: 10.3354/dao 03089

187. Searle CL, Belden LK, Du P, Blaustein AR. Stress and chytridiomycosis: exogenous exposure to corticosterone does not alter amphibian susceptibility to a fungal pathogen. J Exp Zool Part A Ecol Genet Physiol. (2014) 321:243-53. doi: $10.1002 /$ jez. 1855
188. Gabor CR, Knutie SA, Roznik EA, Rohr JR. Are the adverse effects of stressors on amphibians mediated by their effects on stress hormones? Oecologia (2018) 186:393-404. doi: 10.1007/s00442-017-4020-3

189. Gabor CR, Fisher MC, Bosch J. A non-invasive stress assay shows that tadpole populations infected with Batrachochytrium dendrobatidis have elevated corticosterone levels. PLoS ONE (2013) 8:56054. doi: 10.1371/journal.pone.0056054

190. Gabor CR, Fisher MC, Bosch J. Elevated corticosterone levels and changes in amphibian behavior are associated with Batrachochytrium dendrobatidis (Bd) infection and Bd lineage. PLoS ONE (2015) 10:122685. doi: 10.1371/journal.pone.0122685

191. Graham CM, Narayan EJ, McCallum H, Hero JM. Non-invasive monitoring of glucocorticoid physiology within highland and lowland populations of native Australian Great Barred Frog (Mixophyes fasciolatus). General Compar Endocrinol. (2013) 191:24-30. doi: 10.1016/j.ygcen.2013.05.012

192. Kindermann C, Narayan EJ, Hero JM. Urinary corticosterone metabolites and chytridiomycosis disease prevalence in a free-living population of male Stony Creek frogs (Litoria wilcoxii). Compar Biochem Physiol. Mol Integr Physiol. (2012) 162:171-6. doi: 10.1016/j.cbpa.2012.02.018

193. Fites JS, Ramsey JP, Holden WM, Collier SP, Sutherland DM, Reinert LK, et al. The invasive chytrid fungus of amphibians paralyzes lymphocyte responses. Science (2013) 342:366-9. doi: 10.1126/science.1243316

194. Brannelly LA, Roberts AA, Skerratt LF, Berger L. Epidermal cell death in frogs with chytridiomycosis. PeerJ (2017) 2017:e2925. doi: $10.7717 /$ peerj. 2925

195. Rollins-Smith LA, Fites JS, Reinert LK, Shiakolas AR, Umile TP, Minbiole KPC. Immunomodulatory metabolites released by the frog-killing fungus Batrachochytrium dendrobatidis. Infect Immunity (2015) 83:4565-70. doi: 10.1128/IAI.00877-15

196. Grogan LF, Skerratt LF, Berger L, Cashins SD, Trengove RD, Gummer JPA. Chytridiomycosis causes catastrophic organism-wide metabolic dysregulation including profound failure of cellular energy pathways. Sci Rep. (2018) 8:8188. doi: 10.1038/s41598-018-26427-Z

197. Wu N, Yang M, Gaur U, Xu H, Yao Y, Li D. Alpha-ketoglutarate: physiological functions and applications. Biomol Therapeut. (2016) 24:1-8. doi: 10.4062/biomolther.2015.078

Conflict of Interest Statement: The authors declare that the research was conducted in the absence of any commercial or financial relationships that could be construed as a potential conflict of interest.

Copyright (C) 2018 Grogan, Robert, Berger, Skerratt, Scheele, Castley, Newell and McCallum. This is an open-access article distributed under the terms of the Creative Commons Attribution License (CC BY). The use, distribution or reproduction in other forums is permitted, provided the original author(s) and the copyright owner(s) are credited and that the original publication in this journal is cited, in accordance with accepted academic practice. No use, distribution or reproduction is permitted which does not comply with these terms. 